Article

\title{
Optimization of Hyperglycemic Induction in Zebrafish and Evaluation of Its Blood Glucose Level and Metabolite Fingerprint Treated with Psychotria malayana Jack Leaf Extract
}

\author{
Khaled Benchoula ${ }^{1}$, Alfi Khatib ${ }^{2, *}$, Fairuz M. C. Quzwain ${ }^{3, *}{ }^{\circ}$, Che Anuar Che Mohamad ${ }^{1}$, \\ Wan Mohd Azizi Wan Sulaiman ${ }^{1}$, Ridhwan Abdul Wahab ${ }^{4}$, , Qamar Uddin Ahmed ${ }^{2}$ (D), \\ Majid Abdul Ghaffar ${ }^{2}$, Mohd Zuwairi Saiman ${ }^{5}$, Mohamed F. Alajmi ${ }^{6}$ and Hesham El-Seedi ${ }^{7, *}$ \\ 1 Department of Basic Medical Sciences, Kulliyyah of Pharmacy, International Islamic University Malaysia, \\ Kuantan 25200, Pahang, Malaysia; benchoulakhaled@hotmail.fr (K.B.); dranuar@iium.edu.my (C.A.C.M.); \\ drwanazizi@iium.edu.my (W.M.A.W.S.) \\ 2 Department of Pharmaceutical Chemistry, Kulliyyah of Pharmacy, International Islamic University Malaysia, \\ Kuantan 25200, Pahang, Malaysia; quahmed@iium.edu.my (Q.U.A.); jd.majid@yahoo.com (M.A.G.) \\ 3 Faculty of Medicine, Universitas Jambi, Jambi 36122, Indonesia \\ 4 Department of Biomedical Science, Kulliyyah of Allied Health Science, International Islamic \\ University Malaysia, Kuantan 25200, Pahang, Malaysia; ridhwan@iium.edu.my \\ 5 Institute of Biological Sciences, Faculty of Science, University of Malaya, Kuala Lumpur 50603, Malaysia; \\ zuwairi@um.edu.my \\ 6 Department of Pharmacognosy, College of Pharmacy, King Saud University, Riyadh 11451, Saudi Arabia; \\ malajmii@KSU.EDU.SA \\ 7 Division of Pharmacognosy, Department of Medicinal Chemistry, Biomedical Centre, Uppsala University, \\ Box 574, SE-751 23 Uppsala, Sweden \\ * Correspondence: alfikhatib@iium.edu.my (A.K.); fairuzquzwain@gmail.com (F.M.C.Q.); \\ hesham.el-seedi@ilk.uu.se (H.E.-S.)
}

Academic Editor: Derek J. McPhee

Received: 1 March 2019; Accepted: 28 March 2019; Published: 17 April 2019

\begin{abstract}
A standard protocol to develop type 1 diabetes in zebrafish is still uncertain due to unpredictable factors. In this study, an optimized protocol was developed and used to evaluate the anti-diabetic activity of Psychotria malayana leaf. The aims of this study were to develop a type 1 diabetic adult zebrafish model and to evaluate the anti-diabetic activity of the plant extract on the developed model. The ability of streptozotocin and alloxan at a different dose to elevate the blood glucose levels in zebrafish was evaluated. While the anti-diabetic activity of $P$. malayana aqueous extract was evaluated through analysis of blood glucose and LC-MS analysis fingerprinting. The results indicated that a single intraperitoneal injection of $300 \mathrm{mg} / \mathrm{kg}$ alloxan was the optimal dose to elevate the fasting blood glucose in zebrafish. Furthermore, the plant extract at 1, 2, and $3 \mathrm{~g} / \mathrm{kg}$ significantly reduced blood glucose levels in the diabetic zebrafish. In addition, LC-MS-based fingerprinting indicated that $3 \mathrm{~g} / \mathrm{kg}$ plant extract more effective than other doses. Phytosterols, sugar alcohols, sugar acid, free fatty acids, cyclitols, phenolics, and alkaloid were detected in the extract using GC-MS. In conclusion, $P$. malayana leaf aqueous extract showed anti-diabetic activity on the developed type 1 diabetic zebrafish model.
\end{abstract}

Keywords: Type 1 diabetes; zebrafish; Psychotria malayana; alloxan; insulin; streptozotocin 


\section{Introduction}

Zebrafish have been used effectively for drug screening [1]. The advantages of utilizing zebrafish as an animal model are as follows: lower maintenance costs, shorter periods of testing, easily controlled experimental conditions, and most importantly, the genetic similarity between zebrafish and humans (approximately 70\%) [2]. The small size of zebrafish $(3-5 \mathrm{~cm}$ ) allows them to be kept in small tanks [3]. Zebrafish as a vertebrate model shows significant similarity to human physiology. The same carbohydrate-regulated genes in mammals have been detected in zebrafish. Moreover, the zebrafish pancreas has the same functions as its mammalian counterpart regarding glucose homeostasis, including producing and secreting insulin, glucagon, somatostatin and digestive enzymes such as amylase [4]. Furthermore, more than 14,000 genes of zebrafish genome have been studied exclusively and it is fully sequenced. Consequently, it contributes to the establishment of diabetes transgenic model [5]. Despite its advantages, however, working with zebrafish requires handling skills to extract the organs for histological purposes [6].

Considering their advantages, zebrafish have been chosen as an ideal animal model for different diseases including diabetes. Nevertheless, the conditions for inducing type 1 diabetes in adult zebrafish vary depending on unpredictable factors. Thus, an optimized protocol for establishing a type 1 diabetes zebrafish should be developed prior to testing the anti-diabetic activity of potential treatments.

Certain products have shown promising results as hyperglycaemia drugs through screening using in vitro tests. However, some of these potential drugs lost their anti-diabetic activity when tested in mammalian animal models due to pharmacokinetic issues and/or toxicity. In this stage, the zebrafish model is could be used as an alternative screening tool prior to testing on mammalian models [7].

Psychotria malayana Jack is a plant that is widespread throughout tropical and subtropical countries. These plants have been used traditionally to treat gastrointestinal disease, stomach-ache and infections of the female reproductive system in countries such as India, Indonesia, and Brazil. Several studies on the antioxidant, anti-inflammatory and antimicrobial properties of this plant have been reported [7-9]. Due to its curative properties, the species of Psychotria herb are used traditionally for treating diabetes. However, the scientific proof of this plant on diabetes treatment is still lacking. Although the phytochemical studies of Psychotria species showed the presence of alkaloid compounds in the aerial parts of the plant including calycanthine, chimonantine, hodgkinsine, and $N$-methyltryptamine [7], none of these compounds have been reported to exhibit anti-diabetes property. The available approaches for treating diabetes include dietary control, insulin injection, and oral diabetes medications. However, oral medications have been confirmed to be inadequate and causing several side effects, while insulin injection solves the problem only temporarily [10]. Moreover, hypertrophy as a result of many insulin injections in a body area is another complication of insulin therapy [11]. This condition leads to the necessitates finding new drugs or treatments with fewer side effects.

Thus, the aim of this study was to develop a type 1 diabetic adult zebrafish model through chemical induction and to evaluate the anti-diabetic activity of P. malayana leaf extract on the developed model.

\section{Results}

\subsection{Development of the Induced Type 1 Diabetic Zebrafish Model}

\subsubsection{Induction of Type 1 Diabetes Using Streptozotocin}

Intine et al. [12] reported that the established protocol using streptozotocin (STZ) as an inducer (STZ multiple injections at different time points) with a dose of $300 \mathrm{mg} / \mathrm{kg}$ caused an increment of blood glucose level in the zebrafish with low mortality (5\%). However, our study showed high mortality $(80 \%)$ and hypoglycaemia for all samples using this method, in which the level of blood glucose significantly dropped $(p<0.05)$ to $21.5 \pm 2.1,22.3 \pm 3.3$, and $23.8 \pm 4.2 \mathrm{mg} / \mathrm{dL}$ at 24,48 , and $72 \mathrm{~h}$ after STZ injection, respectively (Figure 1). There were no significant differences among the glucose levels 
at different time points $(p>0.05)$ but the glucose levels were significantly different between the STZ treated and the healthy group $(p<0.05)$.

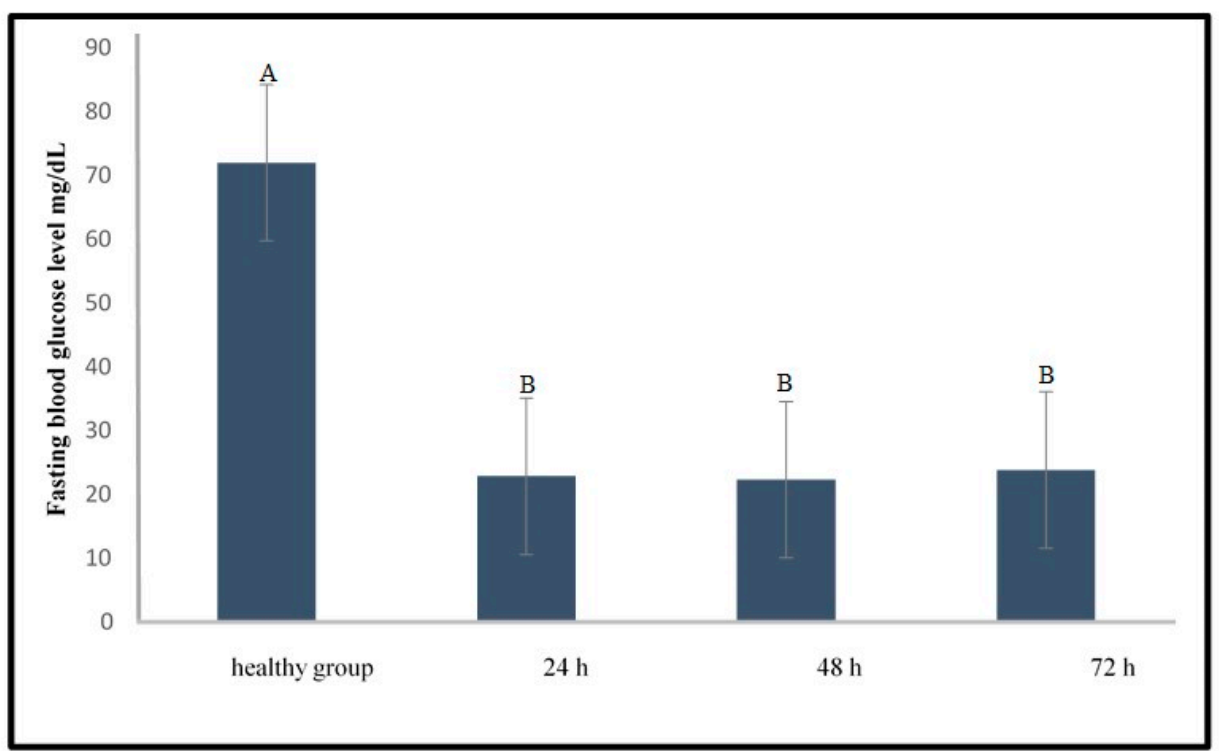

Figure 1. Fasting blood glucose level of healthy and streptozotocin (STZ) treated zebrafish in different timeline following the protocol of Intin et al. [12]. Different capital letter indicates significant difference $(p<0.05)$ among the values, $n=10$.

This unexpected result led us to perform an experiment on the establishment of the type 1 diabetes zebrafish model prior to testing the anti-diabetes activity of the plant extract. Different doses of STZ $(100,300,500$, and $700 \mathrm{mg} / \mathrm{kg})$ were tested as shown in Figure 2. No mortality was observed in any of the zebrafish groups. Furthermore, there was no significant difference between the healthy fish and the zebrafish induced with $100 \mathrm{mg} / \mathrm{kg}$ STZ. In contrast, the STZ injected groups at the higher doses were significantly different from the healthy group $(p<0.05)$. In addition, the blood glucose levels among the 3 groups injected with higher doses of STZ were not significantly different. Hence, $300 \mathrm{mg} / \mathrm{kg} \mathrm{STZ}$ was selected for further optimization work because this dose was the lowest among the effective doses.

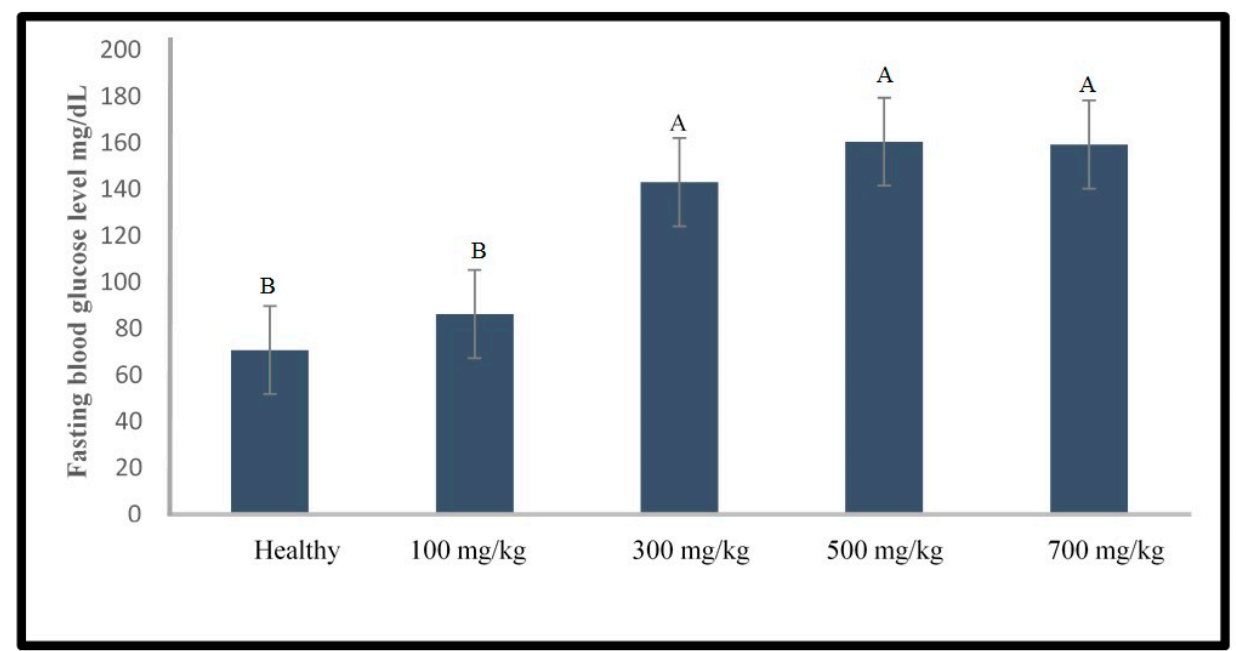

Figure 2. Fasting blood glucose level of zebrafish at $24 \mathrm{~h}$ analyzed after a single injection of STZ with various doses. Different capital letter indicates significant difference $(p<0.05)$ among the values, $n=10$.

Further optimization experiment aimed to evaluate the effect of the selected doses on the fasting blood glucose level of zebrafish at different timelines $(24,48$, and $72 \mathrm{~h})$ after STZ injection. As shown in 
Figure 3, $300 \mathrm{mg} / \mathrm{kg} \mathrm{STZ} \mathrm{was} \mathrm{able} \mathrm{to} \mathrm{significantly}(p<0.05)$ increase the fasting blood glucose level of the zebrafish for up to $24 \mathrm{~h}$ compared to that of the healthy group. Moreover, this STZ dose did not cause mortality on the zebrafish. Nevertheless, this result was unsatisfactory because the blood glucose level dropped rapidly. Hence, a further optimization experiment to prolong the period of hyperglycaemia was performed by exploring another induction agent, alloxan.

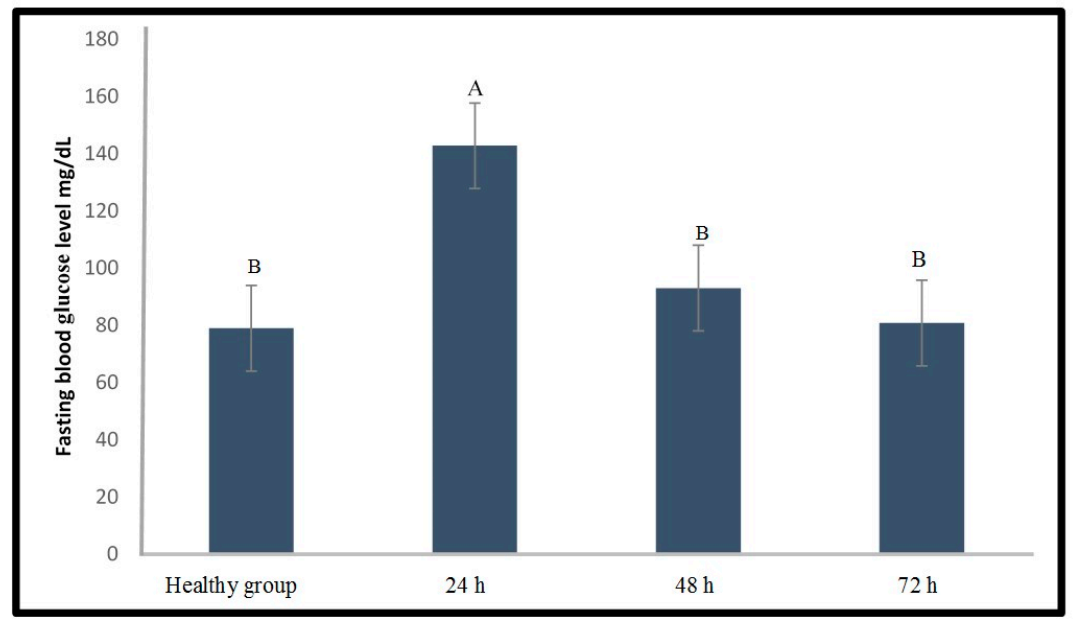

Figure 3. Fasting blood glucose level of zebrafish analyzed at different times after the injection of STZ $(300 \mathrm{mg} / \mathrm{kg})$. Different capital letter indicates significant difference $(p<0.05)$ among the values, $n=10$.

\subsubsection{Induction of Type 1 Diabetes Using Alloxan}

Various doses of alloxan $(100,200,250,300$, and $350 \mathrm{mg} / \mathrm{kg})$ were tested on the effect on the fasting blood glucose level. Figure 4 shows that 250 and $300 \mathrm{mg} / \mathrm{kg}$ alloxan were able to significantly $(p<0.05)$ elevate the blood glucose level at $24 \mathrm{~h}$ after the alloxan injection. Furthermore, at $48 \mathrm{~h}$ after the injection, the blood glucose level of the zebrafish injected with $300 \mathrm{mg} / \mathrm{kg}$ alloxan remained elevated and significantly different $(p<0.05)$ from that of the healthy fish. The mortality rate at the 100,200 , and $250 \mathrm{mg} / \mathrm{kg}$ doses were $0 \%$, and although the mortality rate at the $300 \mathrm{mg} / \mathrm{kg}$ dose was $10 \%$, it was still acceptable [13]. However, the mortality rate at the $350 \mathrm{mg} / \mathrm{kg}$ dose was too high (70\%). Hence, the permitted dose should not exceed $300 \mathrm{mg} / \mathrm{kg}$. Based on this result, $300 \mathrm{mg} / \mathrm{kg}$ was used for evaluation of the hyperglycaemia inducing effect of alloxan over a longer experimental period (8 days). 


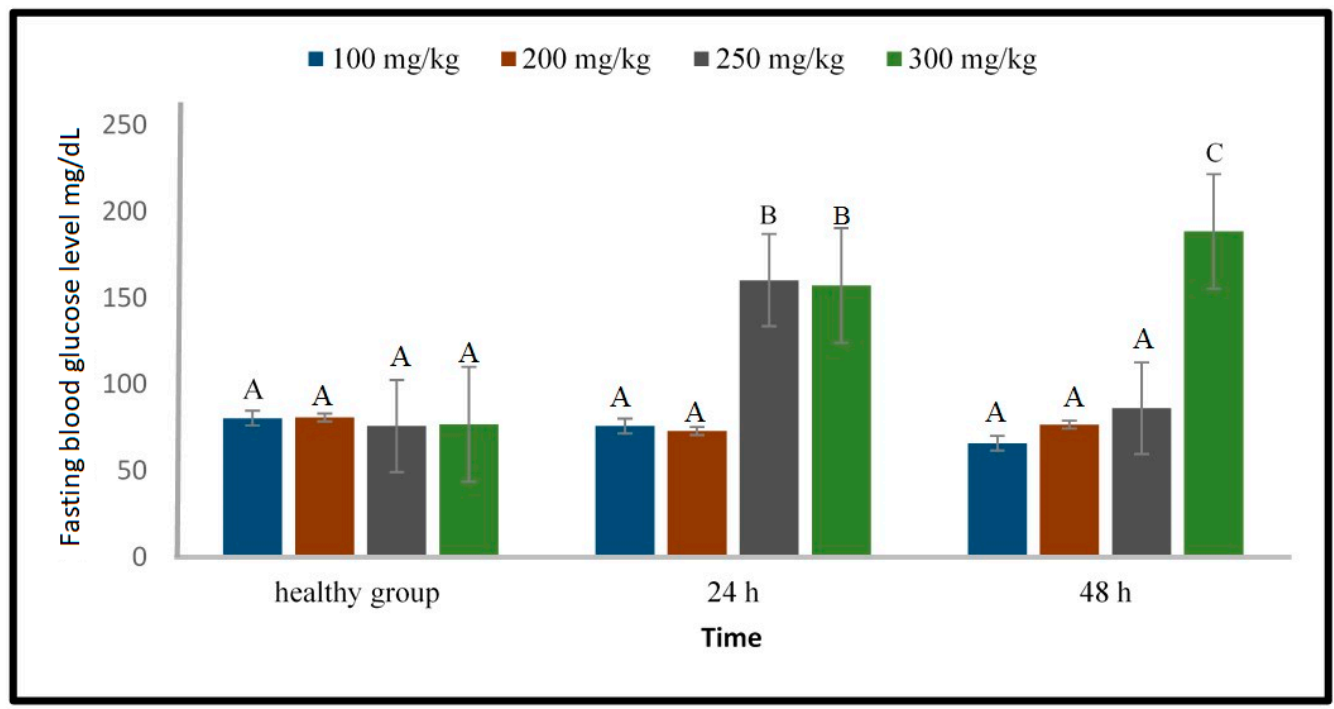

Figure 4. Fasting blood glucose level of zebrafish analyzed after injection of 100, 200, 250 and $300 \mathrm{mg}$ alloxan/kg using $1 \%$ sucrose solution. Different capital letter indicates significant difference $(p<0.05)$ among the values, $n=10$.

Figure 5 shows that blood glucose levels were significantly higher $(p<0.05)$ in most of the alloxan treated zebrafish than in the healthy fish between $24 \mathrm{~h}$ ( 1 day) and $168 \mathrm{~h}$ ( 7 days) after injection with $300 \mathrm{mg}$ alloxan $/ \mathrm{kg}$. The mortality rate was $10 \%$ which was still acceptable.

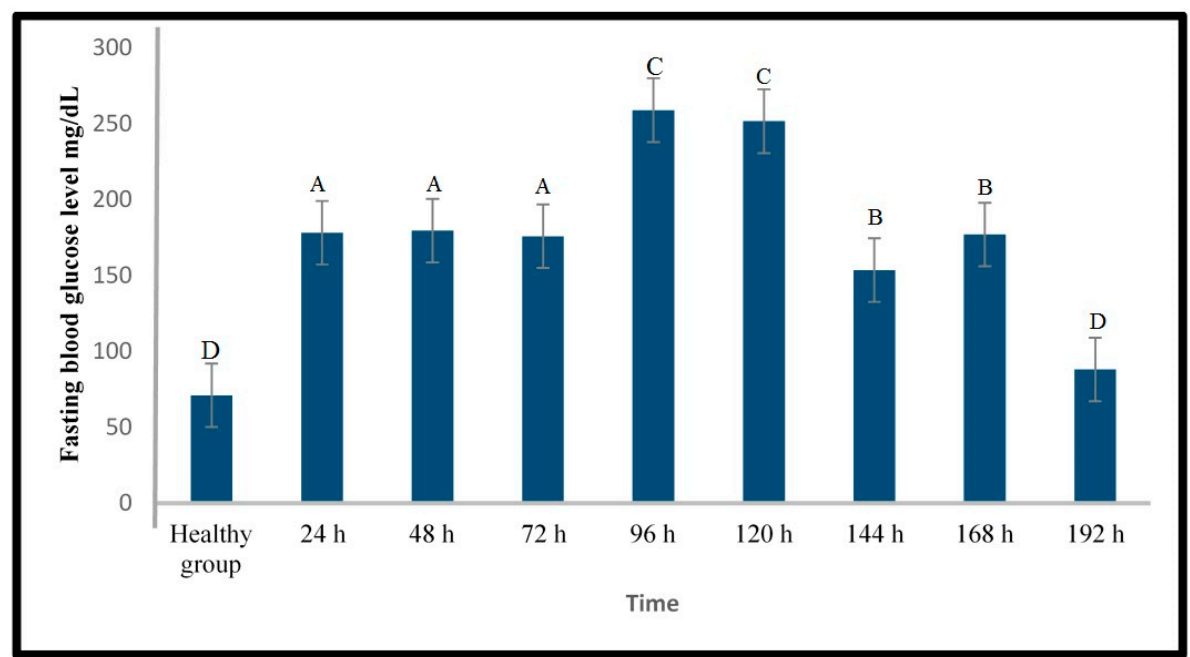

Figure 5. Fasting blood glucose level of zebrafish analyzed after injection of $300 \mathrm{mg}$ alloxan $/ \mathrm{kg}$ for 8 days. Different capital letter indicates significant difference $(p<0.05)$ among the values, $n=10$.

\subsection{Effect of Glibenclamide and Insulin as a Positive Control on Fasting Blood Glucose Level of the Diabetic Zebrafish Model}

Glibenclamide and insulin were used as positive controls for the developed method. Both drugs were injected to evaluate their capability to reduce the fasting blood glucose level of the diabetic zebrafish. As shown in Figure 6, a glibenclamide dose of $1.5 \mathrm{mg} / \mathrm{kg}$ was not effective in reducing the fasting blood glucose level of the diabetic zebrafish, since the blood glucose level was still significantly higher $(p<0.05)$ than that of the healthy group. Nevertheless, no mortality was observed for the glibenclamide treated zebrafish, while the mortality rate of the diabetic group was $10 \%$. 


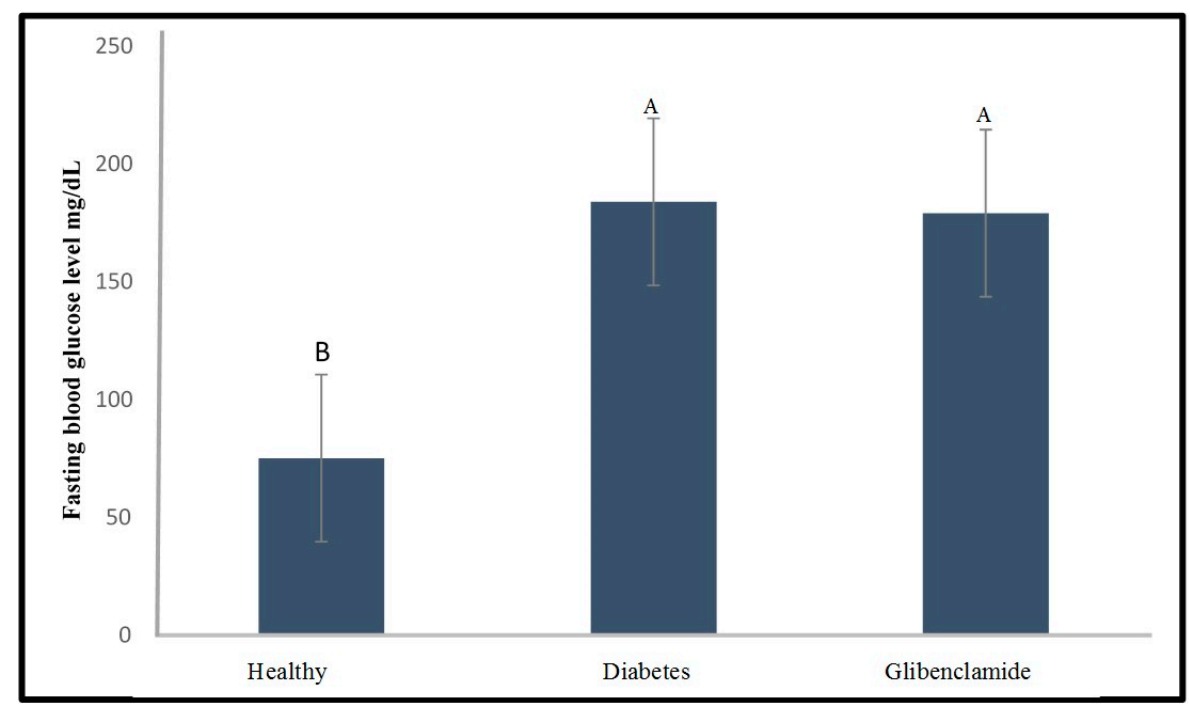

Figure 6. Fasting blood glucose level of the healthy, diabetes, and glibenclamide injected zebrafish (glibenclamide dose $=1.5 \mathrm{mg} / \mathrm{kg}$ ) at $48 \mathrm{~h}$ after the alloxan injection. Different capital letter indicates significant difference $(p<0.05)$ among the values, $n=10$.

Figure 7 indicates that an insulin dose of $1 \mathrm{U} / \mathrm{kg}$ was effective in reducing the blood glucose to normal levels after at $24 \mathrm{~h}$ after the alloxan injection, since no significant difference $(p<0.05)$ was observed in glucose levels between the diabetic group and the healthy group. The mortality rate of the treated zebrafish was $0 \%$ indicating an improvement compared to the diabetic group with a mortality rate of $10 \%$ due to alloxan injection.

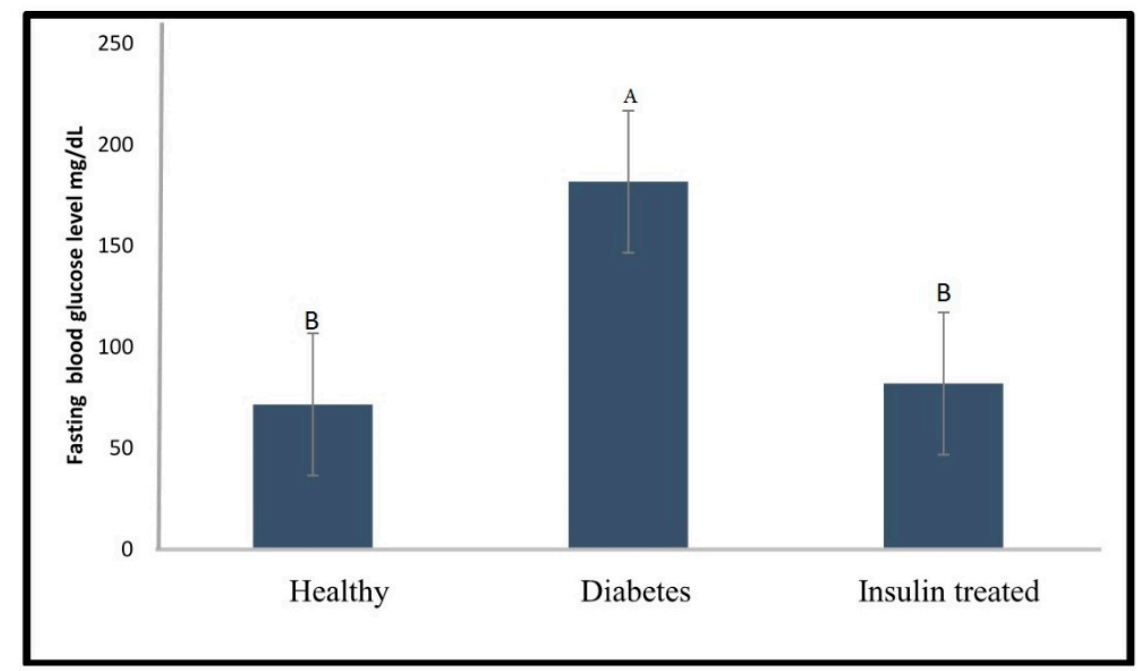

Figure 7. Fasting blood glucose level of healthy, diabetic, and insulin $(1 \mathrm{U} / \mathrm{kg})$ treated zebrafish. Different capital letter indicates significant difference $(p<0.05)$ among the values, $n=10$.

\subsection{Evaluation of the Anti-Diabetic Activity of Psychotria Malayana Leaf on the Alloxan Induced Type 1 Diabetes Zebrafish}

Different doses of the aqueous extract of P. malayana leaf $(1,2$, and $3 \mathrm{~g} / \mathrm{kg})$ were tested on the alloxan-induced type 1 diabetic zebrafish model. Figure 8 indicates that all doses were effective in lowering blood glucose levels which were significantly decreased compared to those in diabetic zebrafish at $48 \mathrm{~h}$ after alloxan injection and $24 \mathrm{~h}$ after the feeding with the plant extract. Plant extract at 1 and $3 \mathrm{~g} / \mathrm{kg}$ was able to reduce the blood glucose level to normal levels. Nevertheless, the blood glucose level of the zebrafish treated with the dose of $2 \mathrm{~g} / \mathrm{kg}$ was still significantly different from that of 
the healthy fish $(p<0.05)$. The positive control, insulin injection, was able to lower the blood glucose level to normal levels. No mortality was observed in the healthy and treated groups. The mortality rate of the diabetic group was $10 \%$.

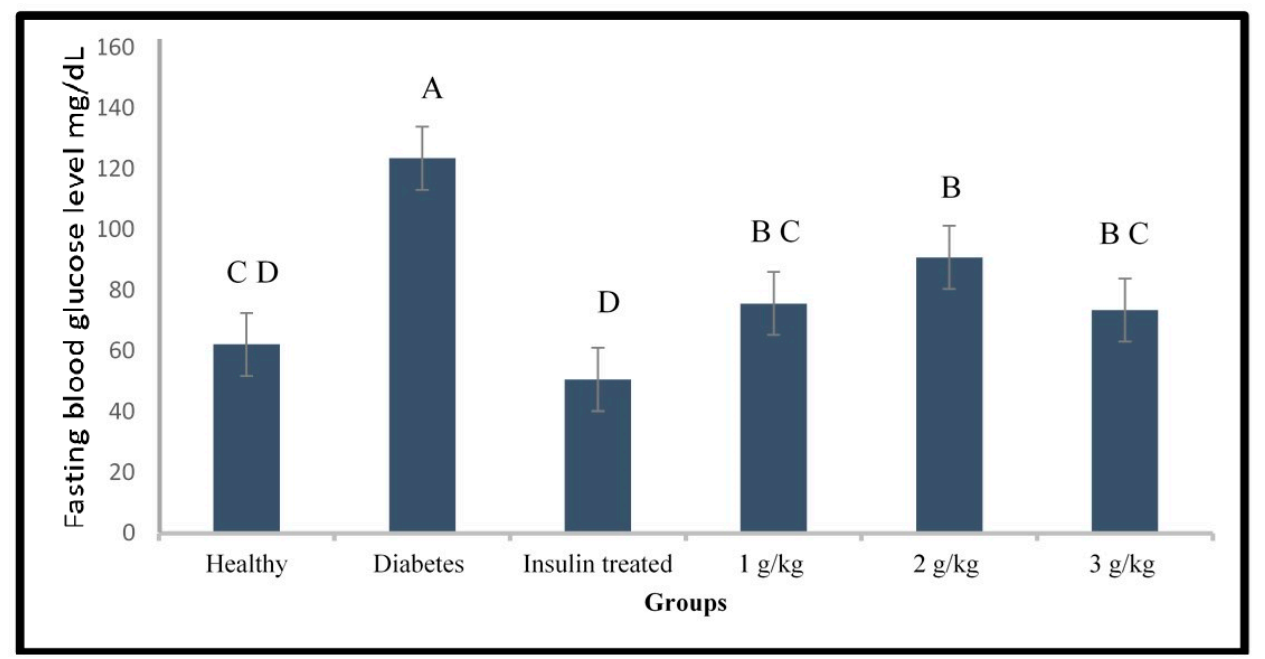

Figure 8. Fasting blood glucose level of diabetic zebrafish after treated with different doses of plant extract, comparing diabetes to healthy and insulin-treated fish. Different capital letter indicates significant difference $(p<0.05)$ among the values, $n=10$.

\subsection{GC-MS Analysis of the P. malayana Leaf Extracts}

Table 1 shows 29 compounds identified in the P. malayana leaf aqueous extract analyzed by GC-MS. All fragmented MS spectra of each ion were compared to the NIST14 database library. Thus, only those compounds with similarity indices higher than $90 \%$ are listed in Table 1. Sugars such as sucrose, D-mannose, D-fructose, D-galactose, D-allose, D-trehalose, D-psicose, D-tagatose, and L-sorbose are among the major compounds present in the extract and dominate more than $50 \%$ of the total peak area. The proportion of minor compounds is shared by different groups of compounds such as phytosterols (beta-sitosterol), sugar alcohols (myo-inositol, xylitol, ribitol, and erythritol), sugar acid (xylonic acid), free fatty acids (stearic acid and palmitic acid), cyclitols (quinic acid and shikimic acid), phenolics (benzenetriol, $\alpha$-tocopherol, and dihydroxyphenylglycol), and alkaloid (piperidine). 
Table 1. Tentative compounds present in the P. malayana aqueous leaf extract detected by GC-MS.

\begin{tabular}{|c|c|c|c|}
\hline Tentative Compounds & Retention Time (min) & Similarity Index & Peak Area $(\%)$ \\
\hline Erythrono-1,4-lactone & 21.1 & 95 & 0.03 \\
\hline Erythritol & 29.4 & 90 & 0.09 \\
\hline Xylonic acid & 35.9 & 86 & 0.02 \\
\hline 1,3,5-Benzetriol & 37.2 & 99 & 0.03 \\
\hline Xylitol & 41.6 & 93 & 0.09 \\
\hline Shikimic acid & 46.7 & 98 & 0.49 \\
\hline Quininic acid & 48.8 & 91 & 1.31 \\
\hline Cyanuric acid & 49.0 & 80 & 0.02 \\
\hline D-Fructose & 49.6 & 91 & 4.91 \\
\hline D-Galactose & 50.5 & 91 & 0.44 \\
\hline D-Allose & 50.7 & 91 & 0.68 \\
\hline D-Mannose & 50.9 & 91 & 9.81 \\
\hline Galactose oxime & 51.7 & 93 & 1.80 \\
\hline L-Sorbose & 52.9 & 93 & 0.72 \\
\hline 3,4-Dihydroxyphenylglycol & 56.9 & 91 & 0.08 \\
\hline Palmitic acid & 57.9 & 99 & 0.01 \\
\hline Myo-inositol & 60.1 & 90 & 5.94 \\
\hline Stearic acid & 67.3 & 98 & 0.05 \\
\hline Cholesta-7,9(11)-dien-3-ol & 78.3 & 95 & 1.09 \\
\hline 1-Monopalmitin & 82.0 & 93 & 0.14 \\
\hline Sucrose & 84.1 & 93 & 33.53 \\
\hline D-Trehalose & 87.8 & 93 & 0.43 \\
\hline Glycerol monostearate & 89.3 & 90 & 0.10 \\
\hline Supraene & 90.3 & 93 & 0.10 \\
\hline 4-(1H-Pyrrol-1-yl)-piperidine & 98.3 & 93 & 0.08 \\
\hline Alpha-tocopherol & 101.2 & 98 & 0.22 \\
\hline Beta-sitosterol & 107.2 & 99 & 0.27 \\
\hline 5-Beta-cholest-24-en-12-one & 108.5 & 90 & 0.07 \\
\hline
\end{tabular}

\subsection{LC-MS Based Fingerprinting of Zebrafish Serum}

The collected serum from different groups of zebrafish (healthy group, diabetes group, insulin-treated group, and the group treated with the plant extract at doses of 1, 2, and $3 \mathrm{~g} / \mathrm{kg}$ were analyzed using LC-MS to investigate their serum fingerprints. Multivariate data analysis with partial least square-discriminant analysis (PLS-DA) was performed on the pre-processed LC-MS dataset to observe the discrimination among the samples. The best fit was achieved with $R^{2} Y_{\text {(cum) }}=0.456$ and $Q^{2}$ (cum) $=0.243$, where $45.6 \%$ of the variation was explained and model predictability was acceptable [14]. Validation of the multivariate calibration was performed using permutation testing. According to [14] the model is valid if the intercepts of $R^{2}$ and $Q^{2}$ are less than 0.4 and -0.05 , respectively. The $R^{2}$ and $Q^{2}$ values in this study were 0.225 and -0.243 , respectively, which were in an acceptable range. as shown in Figure 9.

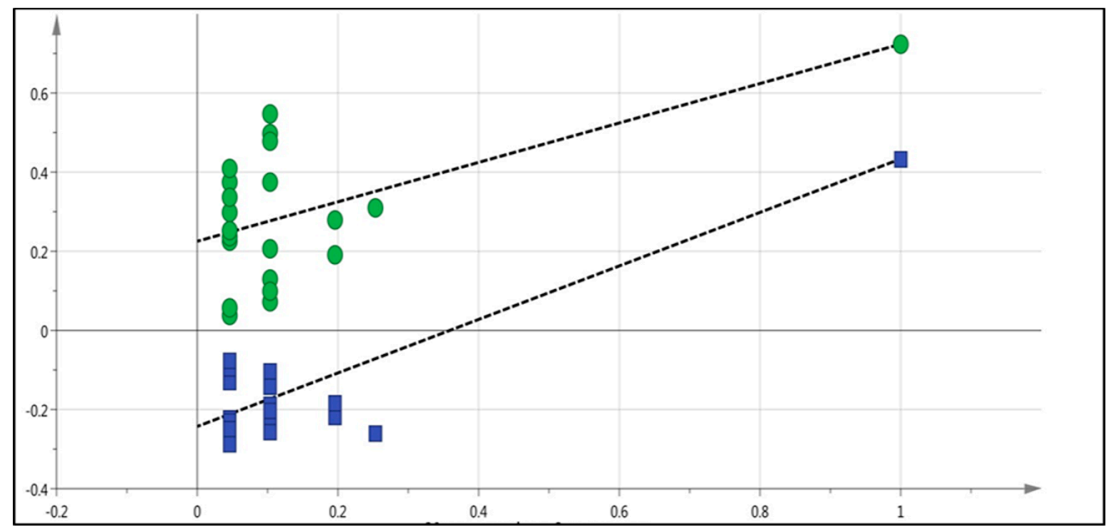

Figure 9. Permutation results of Partial Least Square-Discriminant Analysis (PLS-DA).

Figure 10 shows the score scatter plot displaying the discrimination of the healthy group $(\mathrm{H})$, diabetes group (D), insulin-treated group (I), and groups treated with the plant extract at doses of 
$1 \mathrm{~g} / \mathrm{kg}(1), 2 \mathrm{~g} / \mathrm{kg}$ (2) and $3 \mathrm{~g} / \mathrm{kg}$ (3). The diabetic group was separated from the healthy group alongside Partial Least Square-Discriminant Analysis (PLS-DA) component 2. Furthermore, the group treated with the plant extracts and insulin were shifted closer to the healthy group by PLS-component 2 . Interestingly, PLS-DA component 1 separated the plant extract treated group from the healthy, diabetic, and insulin-treated groups. The higher dose of the plant extract shifted the sample closer to the healthier state.

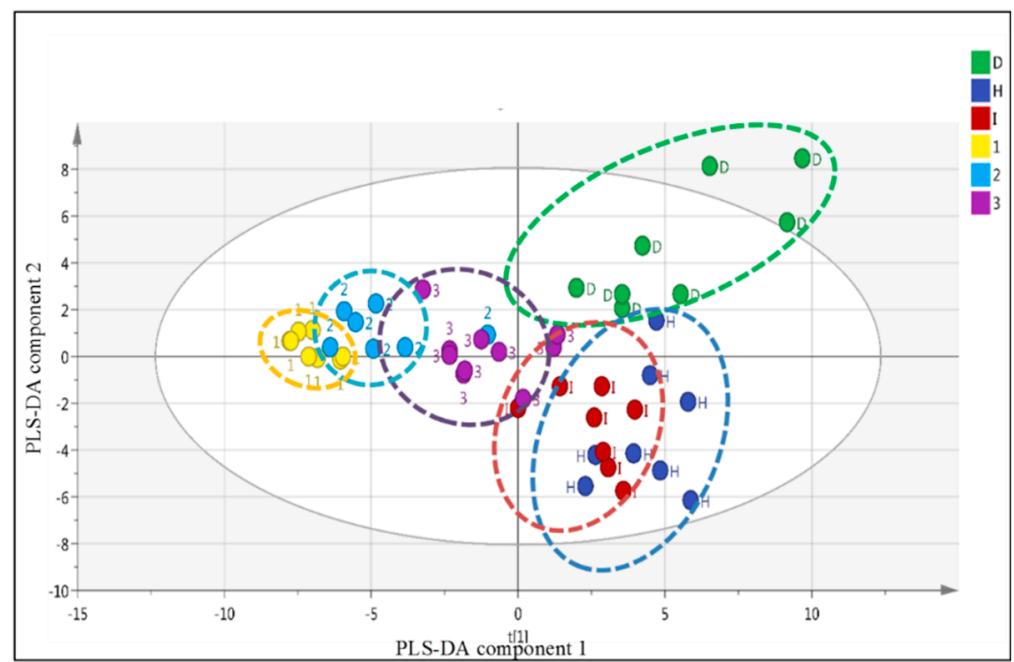

Figure 10. The score scatter plot from the PLS-DA of the healthy group (H), diabetes group (D), insulin-treated group (I), and the plant extract treated groups with the dose of 1 (1), 2 (2), and $3 \mathrm{mg} / \mathrm{kg}$ (3) at $24 \mathrm{~h}$ after the treatments, and $48 \mathrm{~h}$ after the alloxan injection.

\subsection{Histological Examination}

Analysis of paraffin sections of pancreatic islets was performed using haematoxylin and eosin staining of sections obtained from the healthy, diabetic, and insulin-treated zebrafish and the fish treated with $3 \mathrm{~g} / \mathrm{kg}$ plant extract. The islets cells in the healthy group showed a normal structure of (Figure 11a,b). However, both diabetes (Figure 11c,d) and treated zebrafish (Figure 12) showed different islet structure compared to the healthy zebrafish, and there was a considerable loss of cells inside the islets.

Analysis of paraffin-embedded sections of zebrafish liver was performed using haematoxylin and eosin staining of sections obtained from the healthy, diabetic, and insulin-treated zebrafish and the zebrafish treated with $3 \mathrm{~g} / \mathrm{kg}$ plant extract. All hepatocyte structures in all zebrafish were normal except for those in the insulin-treated zebrafish (Figures 13-16), which appeared as nodules of damaged hepatocytes separated by fibrous bands (Figure 15). 

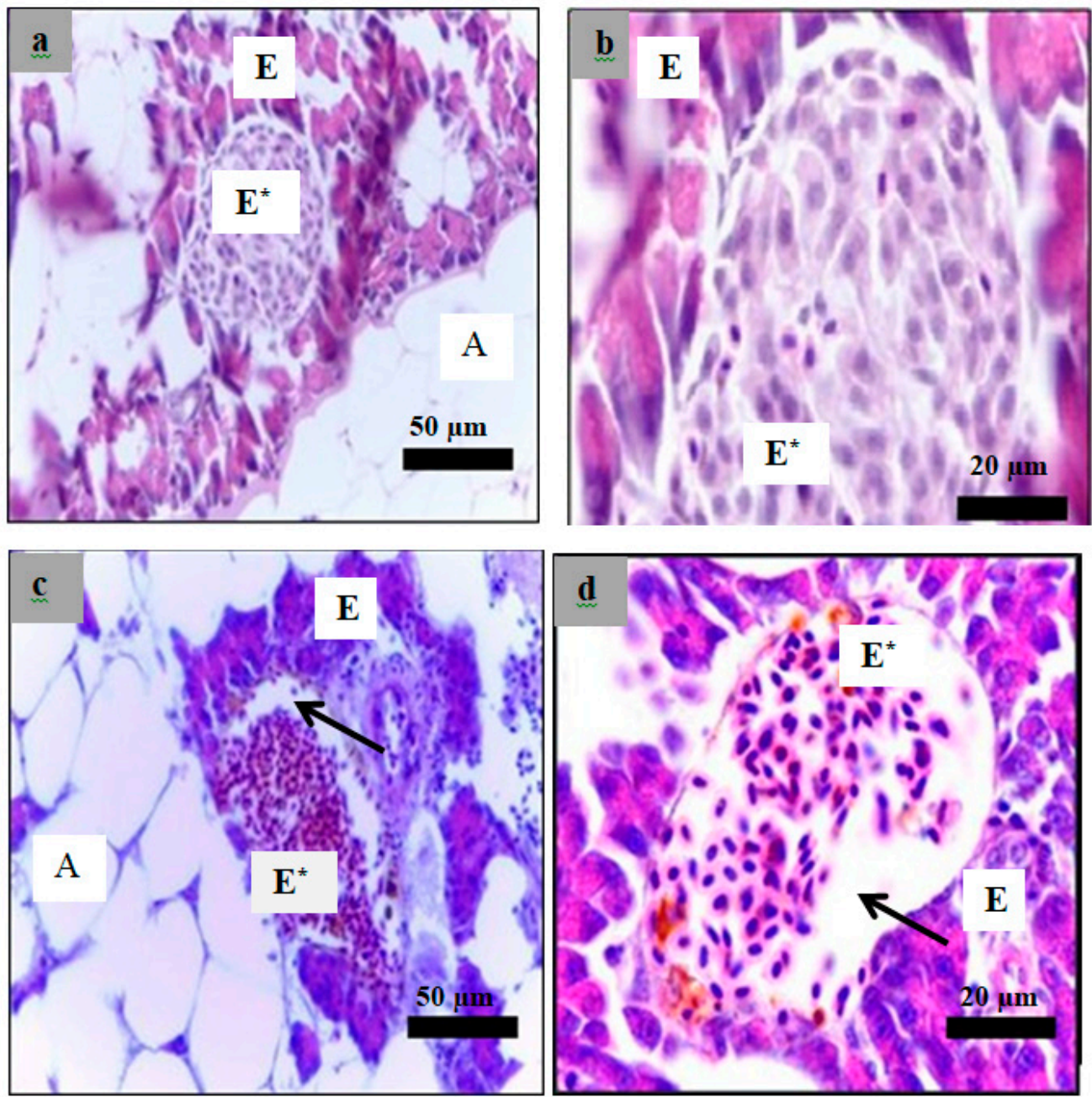

Figure 11. Paraffin section of the islet of the zebrafish pancreas analyzed using hematoxylin and eosin. Healthy group sections ((a): 40× magnification; (b): 100× magnification) showed normal histology of pancreas with high cellularity of Langerhans. Alloxan injected group sections ((c): $40 \times$ magnification; (d): 100 $\times$ magnification) showed a high reduction of endocrine islets cellularity as indicated by the arrows in the alloxan group. $\mathrm{E}^{*}$ : endocrine part, E: exocrine part. A: adipose tissue. 

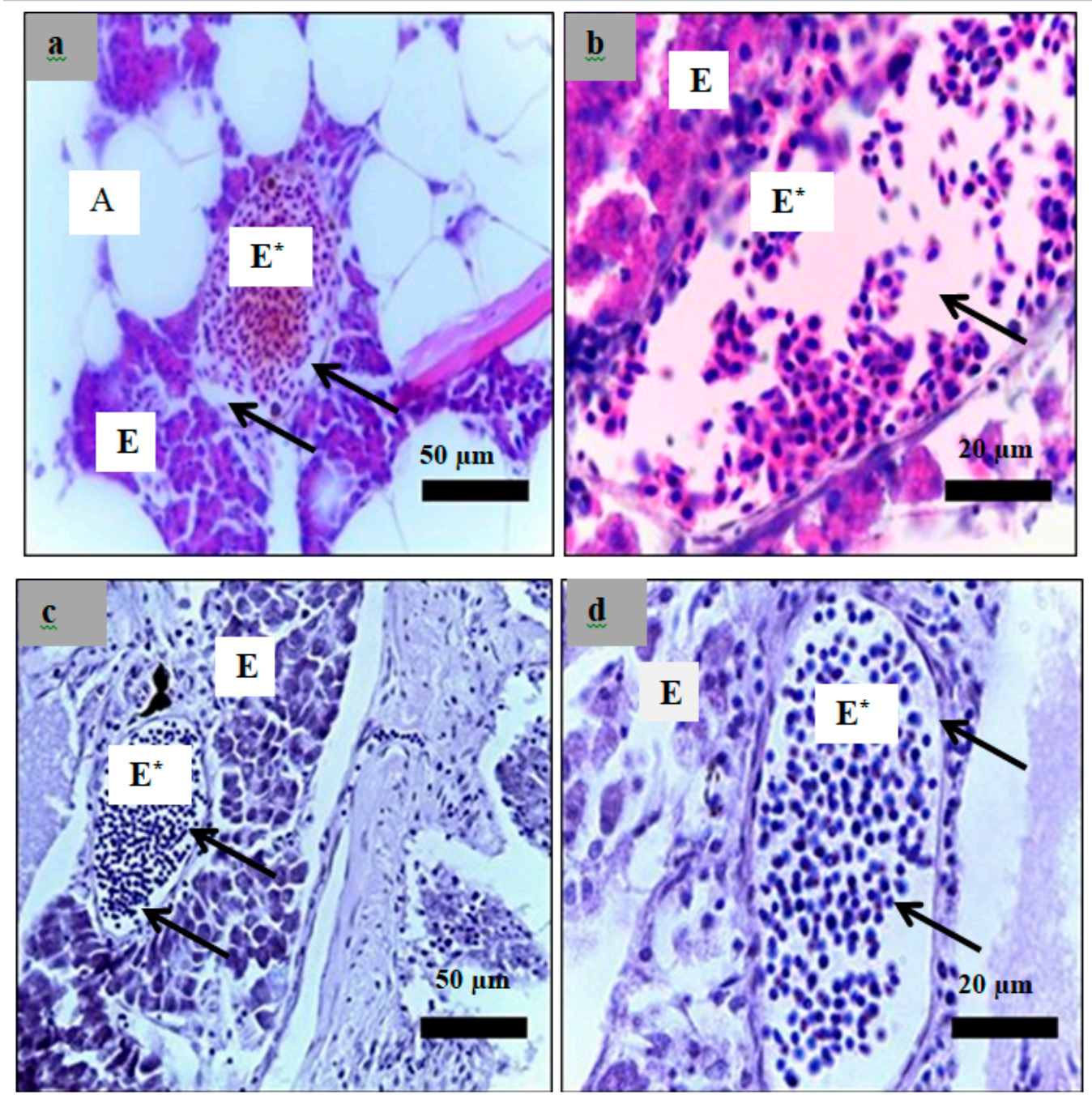

Figure 12. Paraffin section of islet of zebrafish pancreas analyzed using hematoxylin and eosin. (a): The insulin-treated zebrafish (40× magnification); (b): The insulin-treated zebrafish

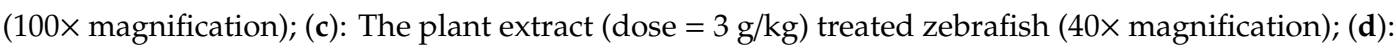
The plant extract (dose $=3 \mathrm{~g} / \mathrm{kg}$ ) treated zebrafish (100× magnification); The islets showed a high reduction of endocrine islets cellularity as indicated by the arrows. $\mathrm{E}^{*}$ : endocrine part, E: exocrine part. A: adipose tissue. 

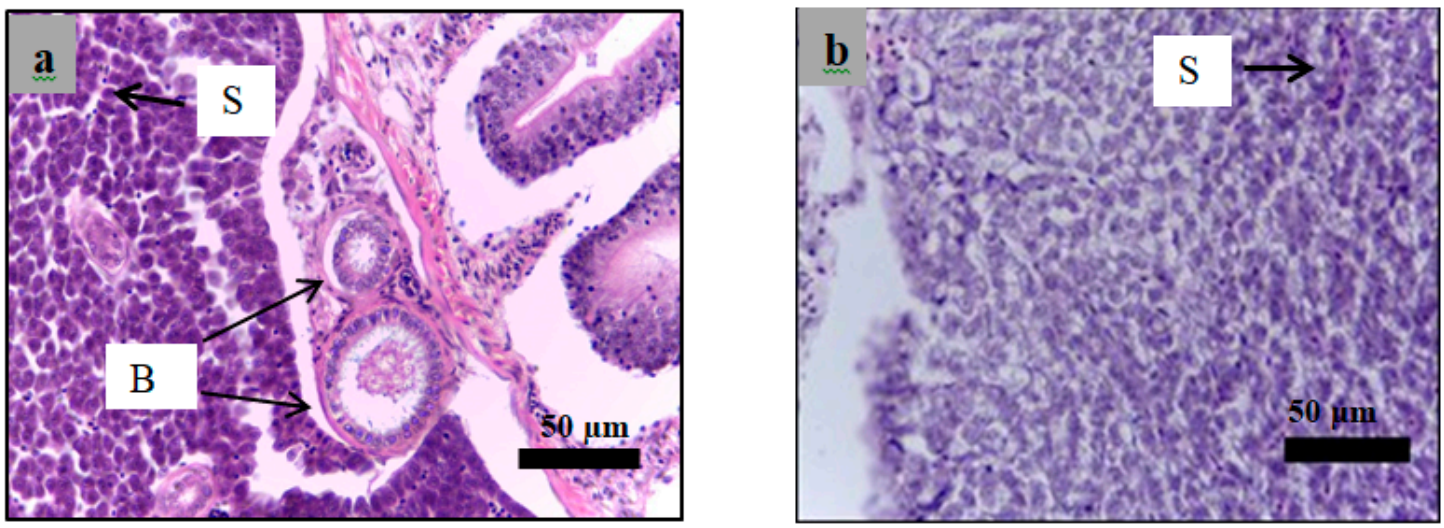

Figure 13. Paraffin section of zebrafish liver analyzed using hematoxylin and eosin staining for the healthy zebrafish $((\mathbf{a}, \mathbf{b})$ : $40 \times$ magnification). Section showed the normal hepatocytes structure. B: bile ductules, S: sinusoidal spaces.
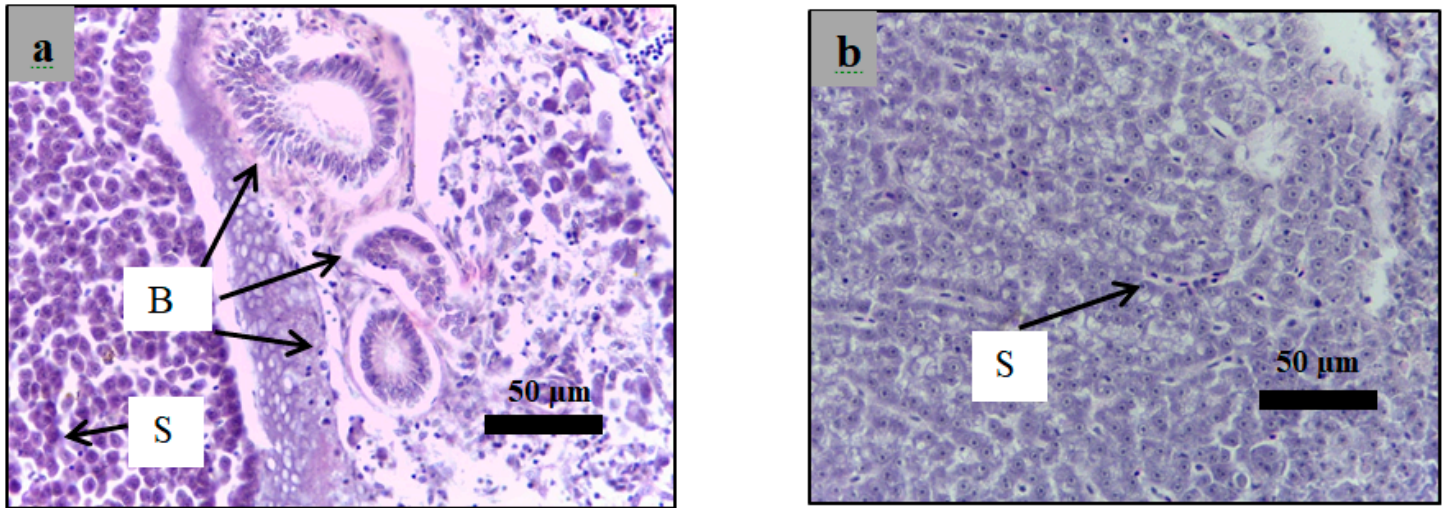

Figure 14. Paraffin section of zebrafish liver analyzed using hematoxylin and eosin staining for the diabetic zebrafish $((\mathbf{a}, \mathbf{b}): 40 \times$ magnification). Section showed the normal structure of hepatocytes comparing to the control. B: bile ductules, S: sinusoidal spaces.
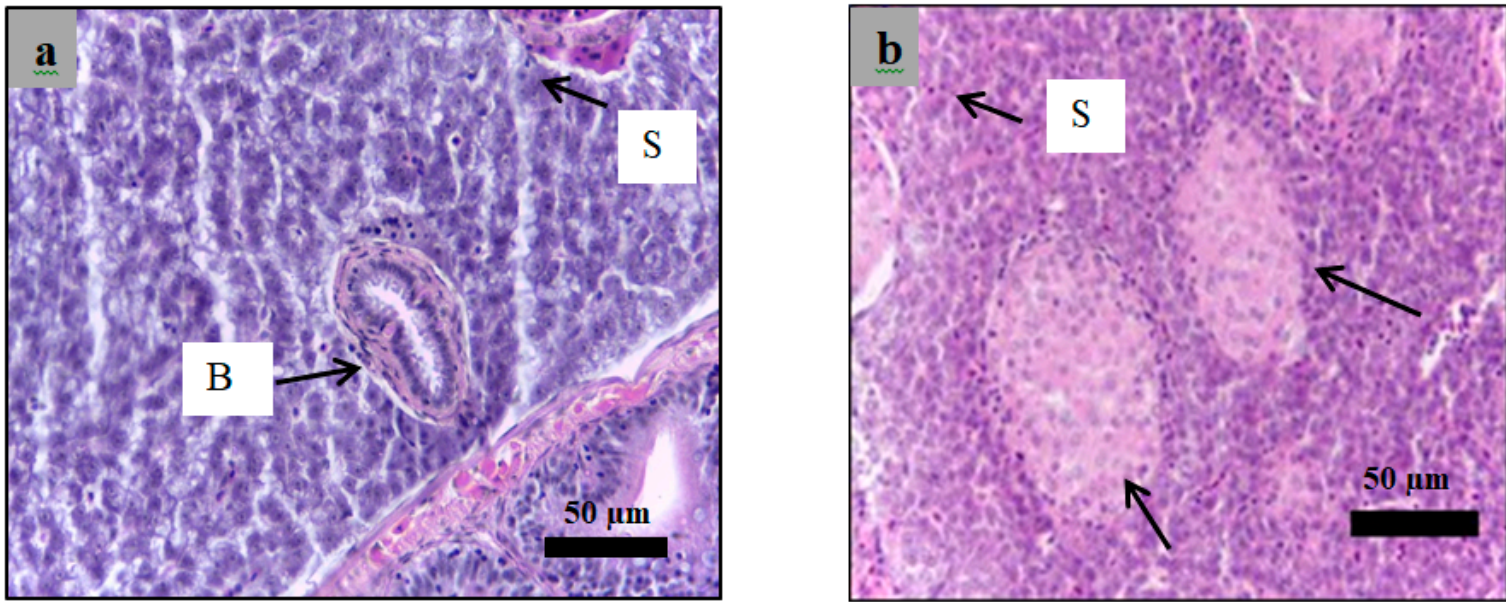

Figure 15. Paraffin section of zebrafish liver analyzed using hematoxylin and eosin staining for the insulin-treated zebrafish ((a,b): 40× magnification). Nodules of damaged hepatocytes are indicated by arrows. B: bile ductules, $\mathrm{S}$ : sinusoidal spaces. 

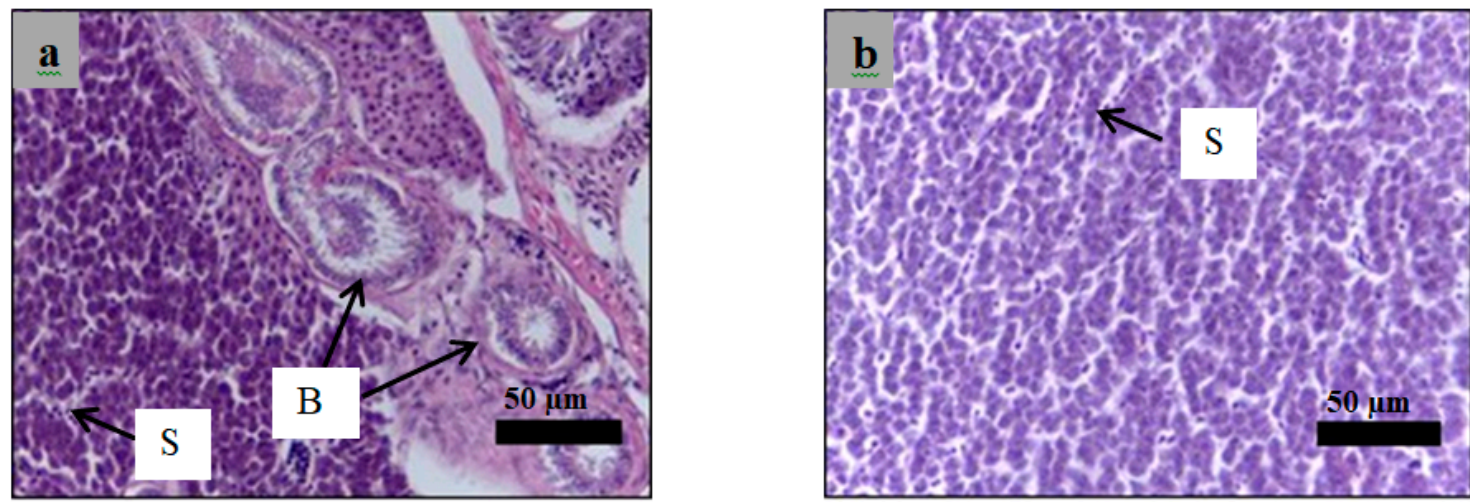

Figure 16. Paraffin section of zebrafish liver analyzed using hematoxylin and eosin staining for the plant extract treated zebrafish ((a,b): 40× magnification). The hepatocytes show normal structure comparing to control. B: bile ductules, S: sinusoidal spaces.

\section{Discussion}

\subsection{Development of the Induced Type 1 Diabetes Zebrafish Model}

The established protocol for inducing type 1 diabetes in zebrafish reported by Reference [12] failed to elevate the fasting blood glucose of the zebrafish in this study. This method caused hypoglycaemic conditions and high mortality, in contrast to the expected results as reported. The high mortality could be due to: (1) multiple injections irritated the cavity of the fish and induced skin inflammation; (2) the long duration of the experiment caused the fish experience stress; (3) the large volume of STZ injected over almost 20 days might have induced toxicity in the fish organs such as the liver [15]. In addition, the injected fish reduced their food intake which is a positive correlation to the drop of the blood glucose levels [16].

These unexpected results led us to optimize the induction condition for the type 1 diabetes zebrafish model. In this study, the intraperitoneal-administration of STZ and alloxan were able to elevate the blood glucose level. The effective period of the alloxan induction at the optimized dose $(300 \mathrm{mg} / \mathrm{kg}$ ) was 7 days. The blood glucose level in the induced fish was significantly $(p<0.05)$ higher than the normal fasting blood glucose level in zebrafish, which is $50-75 \mathrm{mg} / \mathrm{dL}$ according to Reference [17]. The effective period of alloxan induction was longer than that of STZ induction at a higher dose $(500 \mathrm{mg} / \mathrm{kg})$ which lasted only 4 days, although STZ induction did not cause mortality. The mortality rate of the zebrafish induced by $300 \mathrm{mg} / \mathrm{kg}$ alloxan was $10 \%$, which was still acceptable [13]. Increasing the alloxan dose (to $350 \mathrm{mg} / \mathrm{kg}$ ) caused an unacceptable mortality rate $(70 \%)$.

Similar work on the use of alloxan has been reported by Reference [18]. However, the detailed information on the duration of the effective period was uncertain. In addition, data on the histological examination of the affected pancreas and liver were not provided, leading to difficulty in determining whether the model for type 1 diabetes had been established. Moreover, the exposure method was not accurate in terms of dose, since the fish were immersed in the alloxan solution. Furthermore, Moss et al. (2009) reported the impact of high dose STZ on the capability of zebrafish to regenerate the pancreas tissue, however, its effect on the blood glucose level was not a major concern [19].

The diabetogenic characteristic of alloxan was reported by Reference [20]. Alloxan has a chemical structure similar to that of glucose, which helps in penetrating the lipid bilayer of the $\beta$-cells of the pancreas by binding to the GLUT2 glucose transporter [21]. Alloxan selectively destroys $\beta$-cells in two ways. The reduction of alloxan in the cytosol of $\beta$-cells can produce oxygen species, which play a significant role in the necrotic process of $\beta$-cells. The reduction can take place when alloxan reducing agents contain $\mathrm{SH}$ groups, such as glutathione, and cysteine, and in certain cases when ascorbate is present in the cytosol. Furthermore, the inhibition of glucokinase has been considered the secondary effect of alloxan in the $\beta$-cells [22]. Glucokinase is the first enzyme in glycolysis and is involved 
in converting glucose to glucose-6-phosphate, openings the possibility for enormously complex pathways [23].

Both alloxan and STZ cross the phospholipid bilayer of $\beta$-cells, via glucose transporter GLUT2 [24]. However, the effect of STZ is completely different from alloxan. The main effect of STZ in $\beta$-cells is the alkylation of DNA leading to DNA fragmentation [15]. The fragmentation of DNA provokes the repair enzyme, poly (ADP-ribose) polymerase to repair DNA damage. The over-activation of this enzyme can decrease the ATP stores of the cells causing $\beta$-cell necrosis. In addition, STZ can be a nitric oxide (NO) donor. This feature increases the level of cGMP, as a result of the increase in the activity of guanylyl cyclase [25]. The short effect of both alloxan and STZ is due to the high regeneration of the $\beta$-cells in zebrafish. Zebrafish have the capacity to transdifferentiate the $\alpha$-cells to $\beta$-cells in the ablation case of $\beta$-cells ablations through inhibition of insulin-like growth factor (IGF) pathway by increasing secretion of insulin-like growth factor binding protein 1 (Igfbp1) from the liver of zebrafish larvae [26]. Another finding indicated that the centroacinar cells (CACs), a type of ductal cell in adult zebrafish, could contribute to the process of $\beta$-cell regeneration when $\beta$-cells were ablated [27].

\subsection{Effect of Glibenclamide and Insulin on Fasting Blood Glucose Level in Diabetic's Zebrafish Model}

Glibenclamide is a second generation sulfonylurea drug [28]. It is an oral anti-diabetic; that is utilized to treat hyperglycemia. The mechanism of action for glibenclamide is specifically related to $\beta$-cells in the pancreas, and it upgrades insulin secretion by connecting to a particular protein on the surface and prompting the activation of the potassium channels which are ATP-sensitive. The cell membrane will be depolarized caused by an increase in potassium inside the $\beta$-cells, and hence, the calcium channels open, enabling calcium to enter the cytosol of $\beta$-cells. Notably, the increase in intracellular calcium promotes a further combination of insulin granules with the cell membrane and releases insulin [29]. In this investigation, glibenclamide was unable to reduce the blood glucose level of the diabetic zebrafish, which might be caused by an inability of the drug to induce insulin production due to a major loss of cells in the islets of Langerhans in diabetic fish (Figure 7). The drug was unable to promote repair of the damaged $\beta$-cells and therefore failed to induce insulin production through the aforementioned mechanism [30]. In contrast, insulin injection was able to lower and normalize the blood glucose level of the diabetic zebrafish as expected (Figure 8). Notably, insulin injection does not require healthy $\beta$-cells for this effect. Insulin stimulates the translocation of glucose transporter GLUT4 to the plasma membranes of liver and fat cells [31]. The result of this study is in accordance with Reference [32] which reported that insulin injection reduces fasting blood glucose levels in zebrafish with hyperglycemia induced by immersion in a glucose solution.

\subsection{Anti-Diabetic Activity of P. malayana Leaf in Alloxan-Induced Type 1 Diabetic Zebrafish}

High doses of the plant extract $(\geq 1 \mathrm{~g} / \mathrm{kg})$ and a single episode of force-feeding were applied in this study, considering that multiple feedings were impossible due to the irritation of the upper digestive tract caused by the feeding procedure. The plant extract was able to lower and normalize the blood glucose levels of alloxan-induced type 1 diabetic zebrafish in the present study. No significant differences $(p>0.05)$ were observed in the blood glucose levels between the healthy zebrafish group and the groups treated with the plant extract at doses of 1,2 , and $3 \mathrm{~g} / \mathrm{kg}$ (Figure 9). This analytical approach is called a targeted or un-holistic analytical approach because only a targeted metabolite (in this case, was glucose) was analyzed. Nevertheless, this approach might overlook the overall ability of the plant extract to normalize all metabolites in the serum. Hence, LC-MS based fingerprinting with multivariate data analysis was applied to evaluate the overall effect of this plant extract on type 1 diabetic zebrafish.

A supervised multivariate data analysis, PLS-DA, was used to process the LC-MS data set of the samples. Figure 12 shows that PLS-DA was able to detect that different doses of the plant extract on modifying the serum metabolite profile closer to that of the healthy state, which was not observed using the targeted analysis approach. At all doses, the plant extract was able to shift the serum profile 
of the diabetic fish closer to that of the healthy group alongside the PLS-DA component 2. PLS-DA component 1 showed different effects of different doses of the plant extract in normalizing the serum profile of the fish. The zebrafish treated with the plant extract at a dose of $3 \mathrm{~g} / \mathrm{kg}$ was the closest to the healthy group based on PLS-DA component 1 compared to the other doses. In addition, the zebrafish group treated with insulin injection was the closest and very similar to the healthy group among all treatments.

There are enormous medicinal plants showed a positive effect in treating diabetes [33,34]. These plants have possible mechanisms for the plant extract to lower the blood glucose level: lowering glucose production in the liver, reducing glucose absorption in the intestine, increasing peripheral glucose uptake in the muscle and adipose tissue, or increasing insulin production in the $\beta$-cells [35]. The last mechanism was not likely in the present study since this plant extract cannot repair damaged $\beta$-cells as proven by the histological study. Psychotria sp. are able to inhibit $\alpha$-amylase but was unable to inhibit $\alpha$-glucosidase [36]. Moreover, inhibition of both enzymes was correlated with lowering blood glucose levels [37]. A similar result was reported in [38], an investigation of the effect of Petroselinum crispum extract on diabetic rats. P. crispum extract was able to normalize blood glucose levels, but the histopathological investigation showed no effect on the damaged $\beta$-cells in rat pancreas. The authors suggested that the mechanism of action of this plant involved the inhibition of gluconeogenesis and the stimulation of glycolysis.

Histological examination was performed in the present study to evaluate the effect of alloxan on the pancreas of the diabetic zebrafish compared to those of the healthy zebrafish using H\&E staining of paraffin sections. Figure 11 shows that the islets of Langerhans in alloxan injected zebrafish demonstrated a considerable decrease in endocrine islet cellularity as opposed to the healthy zebrafish.

GC-MS detected some compounds in this plant extract (Table 1) which are reported to have anti-diabetes activity. The free fatty acids stearic acid and palmitic acid $[39,40]$ as well as the sugar alcohols myo-inositol, ribitol, and erythritol were reported to have $\alpha$-glucosidase inhibitory activity [41,42]. Other detected groups of compounds such as phytosterol (beta-sitosterol), cyclitols (quinic acid and shikimic acid), 1-monopalmitin, and glycerol monostearate were also reported as $\alpha$-glucosidase inhibitors [43-45]. Myo-inositol and quinic acid were highly abundant in this extract with peak areas of $5.94 \%$ and $1.31 \%$, respectively. Another reported anti-diabetes compound detected in this extract is $\alpha$-tocopherol. Bursell and King [46] reported that the activity of $\alpha$-tocopherol decreases the levels of diacylglycerol and protein kinase $\mathrm{C}$ induced in diabetes or hyperglycaemic conditions.

$\alpha$-Glucosidase plays an important role in the digestion of complex carbohydrates by cleaving oligosaccharides into monosaccharides and is responsible for the final step in the digestive process of carbohydrates that eventually leads to postprandial hyperglycemia. The enzyme's inhibitors will compete with the oligosaccharides for the binding site thus they are classified as the classic competitive inhibitors. An $\alpha$-glucosidase inhibitor is a preferred agent in the management of postprandial hyperglycemia in type-2 diabetes mellitus [47]. Detection of various $\alpha$-glucose inhibitors in the P. malayana extract could explain one possible mechanism by which the extract to lower blood glucose levels via inhibition of carbohydrate digestion and not through the recovery of $\beta$-cells in the pancreas, as proven by histological examination.

\section{Materials and Methods}

\subsection{Chemicals}

Streptozocin and alloxan were purchased from Sigma Aldrich ${ }^{\circledR}$ (Taufkirchen, Germany). Glibenclamide (5 mg for each tablet) was obtained from Aventis Phaema ${ }^{\circledR}$ (Jakarta, Indonesia). Whilst, xylene, haematoxylin, eosin, Disteryne, plasticizer and xylene mixture and all organic solvents were purchased from Fisher Scientific ${ }^{\circledR}$ (New Hampshire, UK). Finally, formaldehyde was procured from Merck KGaA ${ }^{\circledR}$ (Frankfurt, Germany). Human insulin from Novolin ${ }^{\circledR}$ (Bagsvaerd, Denmark) 


\subsection{Maintenance of the Fish}

Mixed-sex adult zebrafish (Danio rerio) at 3-months of age were purchased from a local supplier (Three B Aquatics Sdn. Bhd, Kuala Lumpur, Malaysia) and maintained in 9-L acrylic tanks (50 fish per tank) in a closed, multirack aquatic housing system at Kulliyyah of Pharmacy, International Islamic University Malaysia. All tanks were supplied with well-aerated dechloraminated reverse osmosis (RO) water at $28( \pm 0.1){ }^{\circ} \mathrm{C}$. The water was maintained at $\mathrm{pH} 6.8-7.5$ and salinity $800-1200 \mu \mathrm{S} / \mathrm{cm}$ and circulated through different filters $(120-\mu \mathrm{m}$ filter pad, $50-\mu \mathrm{m}$ canister filter, biological filter, active carbon absorption filter and UV disinfection filter) before reaching the tanks. Fish were maintained under a light/dark cycle of $14 \mathrm{~h} / 10 \mathrm{~h}$ and fed twice daily using an adult zebrafish complete diet (Zeigler Bros Inc, Gardners, PA) containing $55 \%$ crude protein, $15 \%$ crude fat, $1.5 \%$ crude fiber and $12 \%$ water.

\subsection{Induction of Type 1 Diabetes Using Streptozotocin}

A protocol described by Intine et al. [12] was followed to induce diabetes in zebrafish. The fish were anesthetized by exposure to water at 15 and $5{ }^{\circ} \mathrm{C}$ for a few seconds prior to streptozotocin (STZ) injection. STZ solution was prepared by dissolving $10 \mathrm{mg}$ of STZ in $1 \mathrm{~mL}$ of citrate buffer ( $\mathrm{pH}$ 4.7). The fish were injected intraperitoneally with $300 \mathrm{mg} / \mathrm{kg} \mathrm{STZ}$ solution on days 1, 3, 5, 12, and 19. Unfortunately, the fish developed hypoglycaemia, and mortality was high; thus, the following modified induction protocol was used to improve the result. The fish were fasted for $12 \mathrm{~h}$ (overnight) prior to STZ injection. The anaesthetized fish were injected intraperitoneally with STZ at 4 different doses $(100,300,500$ and $700 \mathrm{mg} / \mathrm{kg})$. The healthy control group was injected with citrate buffer ( $\mathrm{pH}$ 4.7). Subsequently, after the injection, the fish were fasted for $24 \mathrm{~h}$ prior to blood collection. The blood was withdrawn from the heart using a syringe; the needle was pushed carefully under the gill, and approximately $10 \mu \mathrm{L}$ of blood withdrawn. Lastly, the blood glucose level was measured using a glucometer (Easy Touch ${ }^{\circledR}$ GCU glucometer, Miaoli county, Taiwan).

\subsection{Induction of Type 1 Diabetes Using Alloxan}

In this step the protocol described in Reference [48] with slight modification was followed. The fish fasted overnight before alloxan injection. The anaesthetized fish were injected intraperitoneally with $1 \%(w / v)$ alloxan in citrate buffer (0.1 M, pH 4.7) at different doses (100, 200, 250, 300 and $350 \mathrm{mg} / \mathrm{kg})$. Healthy control fish were injected with only citrate buffer $(0.1 \mathrm{M}, \mathrm{pH} 4.7)$. After the injection, the fish was treated with sucrose according to the following procedure: The fish was immersed in $1 \%$ sucrose for $6 \mathrm{~h}$, and then transferred to fresh water for $3 \mathrm{~h}$, where the water was refreshed every $60 \mathrm{~min}$ to ensure that all sucrose was cleared from the fish. The fish were then fed a normal diet and maintained overnight.

This procedure was repeated until blood was collected from the last zebrafish group. Blood was collected every $24 \mathrm{~h}$ after the sucrose treatment as mentioned above. The fish were fasted for $24 \mathrm{~h}$ prior to blood withdrawal. Finally, the blood glucose level was measured using a glucometer.

\subsection{Treatment of the Fish}

The fish were divided into 4 groups containing 10 fish in each group. Three groups were injected with alloxan $(300 \mathrm{mg} / \mathrm{kg})$. After $24 \mathrm{~h}$ following the alloxan injection, the first group was injected intraperitoneally with glibenclamide at the dose of $2 \mathrm{mg} / \mathrm{kg}$. Glibenclamide was dissolved in 1\% dimethylsulfoxide (in water) to obtain a final concentration of $100 \mu \mathrm{M}$ and sonicated for $15 \mathrm{~min}$. The second group was injected with insulin at the dose of $1 \mathrm{U} / \mathrm{kg}$. The last group (the healthy group) was injected with water. Finally, blood was collected from each fish, and the blood glucose level was measured as described in the previous section $[49,50]$. 


\subsection{Preparation of the Plant Extract and Force-Feeding Procedure}

The plant material was obtained from Cermin Nan Gedang at Sarolangun District, Jambi, Indonesia, and identified by a botanist, Shamsul Khamis. It was deposited at Kulliyyah of Pharmacy, International Islamic University Malaysia, Kuantan, Malaysia, with voucher specimen number PIIUM008-2. The fresh leaves of the plant were cleaned with water and then dried at room temperature $\left(27 \pm 1^{\circ} \mathrm{C}\right)$ for 7 days. The dried leaves were ground and stored at $-80{ }^{\circ} \mathrm{C}$ before further treatment. As much as $3 \mathrm{~g}$ of the leaf powder was transferred into a $50 \mathrm{~mL}$ beaker, $30 \mathrm{~mL}$ of distilled water was added, and the mixture was boiled for $15 \mathrm{~min}$ until the volume of the water was reduced to approximately $20 \mathrm{~mL}$. The extract was filtered using Whatman no. 1 filter paper, and the supernatant was collected and stored at $-80{ }^{\circ} \mathrm{C}$ prior to force-feeding into the zebrafish.

The optimized type 1 diabetic zebrafish model described above was used to test the efficacy of the plant extract. New groups of healthy, diabetic, and positive control zebrafish $(n=10)$ were developed alongside the plant extract treated zebrafish. The fish were fasted overnight prior to force-feeding. The plant extract, at doses of 1,2 and $3 \mathrm{~g} / \mathrm{kg}$, was force fed to the diabetic zebrafish.

\subsection{Derivatization Procedure of P. malayana Extract}

The plant extract was derivatized prior to injection into GC-MS following the protocol described in Reference [51]. The extract of $25 \mathrm{mg}$ was added in a $2 \mathrm{~mL}$ centrifuge tube, dissolved in $50 \mu \mathrm{L}$ of pyridine and sonicated (Elma, S 30H Ultrasonic, South Orange, NJ, USA) for $10 \mathrm{~min}$ at $30{ }^{\circ} \mathrm{C}$. Methoxyamine $\mathrm{HCl}(100 \mu \mathrm{L}, 20 \mathrm{mg} / \mathrm{mL}$ in pyridine) was added to the sample solution and vortexed. Followed by incubation for $2 \mathrm{~h}$ at $60^{\circ} \mathrm{C}$ in an incubator shaker (Innova 4000-M1192, Weender Landstr, Goettingen, Germany). The tube was further incubated for $30 \mathrm{~min}$ at $60^{\circ} \mathrm{C}$ after the addition of $300 \mu \mathrm{L}$ of N-Methyl-N-(trimethylsilyl) trifluoroacetamide (MSTFA). Lastly, the solution was filtered via syringe filter and covered with aluminum foil and left to stand overnight at room temperature $\left(25 \pm 0.5^{\circ} \mathrm{C}\right)$ prior to injection into GC-MS.

\subsection{GC-MS Analysis of P. malayana Extract}

GC-MS analysis was accomplished following the protocol described in Reference [51] with slight modification. The derivatized sample $(\mu \mathrm{L})$ was injected in the splitless mode into the GC-MS system, which consisted of an Agilent 6890 GC-MS and an HP 5973 mass selective detector. The DB-5MS 5\% phenyl methyl siloxane column with an inner diameter (ID) of $250 \mu \mathrm{m}$ and a film thickness of $0.25 \mu \mathrm{m}$ (Agilent Technologies Inc, Santa Clara, CA, USA) was used. The initial oven temperature was set to $85^{\circ} \mathrm{C}$, and then increased to a target temperature of $315^{\circ} \mathrm{C}$ at a rate of $2^{\circ} \mathrm{C} / \mathrm{min}$ with a total running time of $120 \mathrm{~min}$. Helium was used as the carrier gas with a flow rate of $1 \mathrm{~mL} / \mathrm{min}$. The injector and ion source temperatures were set to 250 and $280^{\circ} \mathrm{C}$, respectively. Mass spectra were acquired using a full scan and a monitoring mode with a mass scan range of 50 to $550 \mathrm{~m} / \mathrm{z}$. The spectra for each of the chromatogram peaks were compared with those in the NIST14 database library. The chromatogram and mass spectra were processed using an Agilent ChemStation, Automated Mass Spectral Deconvolution and Identification System and Agilent's Deconvoluted Reporting Software (Agilent Technologies Inc, Santa Clara, CA, USA).

\subsection{LC-MS-Q TOF Based Fingerprinting}

The zebrafish blood was centrifuged at 10,000 rpm for $10 \mathrm{~min}$ to separate the serum (supernatant) from the debris (precipitate). The serum was then immersed in liquid nitrogen for enzyme inactivation. Subsequently, $5 \mu \mathrm{L}$ of the serum was added to $250 \mu \mathrm{L}$ of water: methanol $(1: 1, v / v)$, vortexed and centrifuged under 10,000 rpm for $10 \mathrm{~min}$. Then, $200 \mu \mathrm{L}$ of the supernatant was transferred into the LC-MS insert vial and stored at $-80^{\circ} \mathrm{C}$ prior to the LC-MS analysis. Ten microliters of the sample were injected into the LC-MS-Q TOF system. A $\mathrm{C}_{18}$ column (Phenomenax Kinetex core-shell technology $100 \AA, 250 \mathrm{~mm} \times 4.6 \mathrm{~mm}, 5 \mu \mathrm{m})$ was used as the stationary phase. The solvent system was a gradient 
from 5 to $100 \%$ methanol in water with $0.1 \%$ phosphoric acid for $10 \mathrm{~min}$ and then continued with absolute methanol for another $10 \mathrm{~min}$ with a flow rate of $0.3 \mathrm{~mL} /$ minute. Electrospray ionization in the positive mode without fragmentation was applied. The voltages of the capillary and sampling cone was set at $3 \mathrm{kV}$ and $40 \mathrm{kV}$, respectively. The desolvation flow was set to $700 \mathrm{~L} / \mathrm{h}$ at $300{ }^{\circ} \mathrm{C}$, while the source temperature was set to $110^{\circ} \mathrm{C}$. The MS data were collected in the range of $\mathrm{m} / \mathrm{z} 100$ to 1000 with a scan time of $0.2 \mathrm{~s}$ and an interscan delay time of $0.02 \mathrm{~s}$. Leucine-enkephalin (556.2771 Da; $200 \mathrm{~mole}$ ) in ESI positive mode, was used as the lock spray for the analysis with a flow rate of $3 \mu \mathrm{L} / \mathrm{min}$ [52].

The data was pre-processed using ACD/Spec Manager v.12.00 lab software (Advanced Chemistry Development, Inc., ACD/Labs Toronto, Canada) and converted into cdf file. All spectra were further re-processed for peak filtering, peak identification, peak matching, retention time correction and peak filing using the online MZmine software and converted to an excel format file. Finally, the data was statistically calculated using the SIMCA 14.0 software (Umeå, Sweden).

\subsection{Histological Study}

\subsubsection{Organ Harvesting and Fixation}

The method which uses $10 \%$ formaldehyde as the main fixative agent was applied in this study in accordance with the established protocol [53-55] with some modifications. The fish were sacrificed using hypothermal shock through immersion in water at $0{ }^{\circ} \mathrm{C}$ for $3 \mathrm{~min}$ [56]. Following euthanasia, the fish were gently handled and dried using a tissue paper and immediately preserved in $10 \%$ formaldehyde for $24 \mathrm{~h}$. On the following day, the fish were removed from the formaldehyde solution and the whole internal organs except the heart and kidney were harvested and preserved in the formaldehyde solution for another $24 \mathrm{~h}$.

\subsubsection{Tissue Processing}

The organ's tissues were then exposed to the consecutive immersion of the tissue through various concentration of ethanol $(50 \%, 70 \%, 80 \%, 95 \%$, and $100 \%, v / v)$ for $40-60 \mathrm{~min}$ each. Subsequently, the tissues were exposed to ethanol -toluene solution (1:1) for $15 \mathrm{~min}$ and followed by the overnight incubation in the absolute toluene. In the following day, the tissues were exposed to three distinctive paraffin waxes for $1 \mathrm{~h}$ each under $60^{\circ} \mathrm{C}$ in an oven. Upon completion, the tissues were inserted into paraffin wax to facilitate desired orientation for sectioning.

\subsubsection{Tissue Sectioning and Hematoxyline and Eosin (H and E) Staining}

The tissue was cut using Leica RM2135 microtome which set at $6 \mu \mathrm{m}$ thickness and subsequently placed on the slides. The tissue slides were then dried on a hot plate at $37-42{ }^{\circ} \mathrm{C}$ for $24 \mathrm{~h}$. After that, the slides were consecutively dipped two times in the absolute xylene for $5 \mathrm{~min}$ respectively. Subsequently, they were serially placed in different concentrations of ethanol $(100 \%, 90 \%, 80 \%$, $70 \%$ and $50 \%$ ) for $3 \mathrm{~min}$ in each concentration. Following different exposure to different ethanol concentration, the tissue slides stained with $\mathrm{H}$ and $\mathrm{E}$ as per usual practice in histology i.e., through exposure to haematoxyline for $15 \mathrm{~min}$. The tissue slides were then cleaned under running water for approximately $10 \mathrm{~min}$, followed by immersion in $1 \%$ acid alcohol to expel the excess of haematoxylin. The second recoloring step was applied through the exposure of the slides in an eosin solution for $3 \mathrm{~s}$. After that recent exposure, they were again immersed in different concentration of ethanol $(95 \%, 95 \%$ $100 \%, 100 \%$ ) for $3 \mathrm{~min}$ in each concentration, followed by two consecutive immersions in the absolute xylene for $5 \mathrm{~min}$ each. Finally, the slide was covered with the layer blend of disteryne, plasticizer and xylene (DPX) mixture before they were cover-slipped. The covered slides were kept under room temperature $\left(27 \pm 1^{\circ} \mathrm{C}\right)$ for at least $24 \mathrm{~h}$ prior to observation under a light microscope. 


\section{Statistical Analysis}

The data were calculated using the one-way analysis of variance (ANOVA) and processed utilizing Minitab version 16 (Coventry, London, UK). Tukey's test was applied to determine the differences within the groups. The results were presented as mean \pm standard deviation, while the results with a p-value below 0.05 were considered significantly different. The multivariate data analysis was performed using SIMCA version 14.0 (Umeå, Sweden). The data was UV scaled and centered prior to fitting. The Partial Least Square-Discriminant Analysis was applied to fit the data. Subsequently, the model was validated through a permutation test. The score scatters plot was used to display the separation among the samples.

\section{Conclusions}

This study has succeeded in optimizing the induction conditions for the type 1 diabetes zebrafish model. A single injection of alloxan at a dose of $300 \mathrm{mg} / \mathrm{kg}$ can induce a type 1diabetes in zebrafish lasts for 7 days after the alloxan injection. Furthermore, insulin injection can be used as a positive control to normalize the serum profile. The reliability of this model was verified by its capability to prove the blood glucose lowering effect of insulin and the P. malayana leaf extract in zebrafish.

The extract was able to lower and normalize the blood glucose levels of diabetic zebrafish. In addition, LC-MS-based fingerprinting indicated that $3 \mathrm{~g} / \mathrm{kg}$ plant extract shifted the serum metabolite profile of diabetic zebrafish closest to that of the healthy zebrafish compared to the other doses of the plant extract. The mechanism by which this plant lowered the blood glucose level was not through the recovery of the pancreatic cell since this extract could not repair the considerable reduction in pancreatic $\beta$-cells. In addition, the plant extract did not alter the healthy liver structure of the zebrafish. This report is the first to describe the anti-diabetic activity of this plant indicating its potential as an anti-diabetic agent.

Author Contributions: Conceptualization, A.K.; Data curation, K.B., A.K. and W.M.A.W.S.; Formal analysis, K.B., C.A.C.M., R.A.W. and Q.U.A.; Funding acquisition, A.K., F.M.C.Q., M.F.A. and H.E.-S.; Investigation, K.B.; Methodology, K.B.; Project administration, A.K. and F.M.C.Q.; Resources, K.B., R.A.W. and M.Z.S.; Software, A.K.; Supervision, A.K., W.M.A.W.S. and R.A.W.; Validation, A.K., C.A.C.M. and M.A.G.; Writing-original draft, K.B.; Writing-review \& editing, A.K., F.M.C.Q., C.A.C.M., W.M.A.W.S., R.A.W., Q.U.A., M.A.G., M.Z.S., M.F.A. and H.E.-S.

Funding: This research was funded by International Islamic University Malaysia (Publication Research Initiative Grant fund-PRIGS18-027-0027); Faculty of Medicine, Jambi University, Indonesia (Skema Penelitian Program Doktor PNBP, 929/UN.21.17/LT/2018, 16 ${ }^{\text {th }}$ April 2018); and King Saud University (International Scientific Partnership Program-ISPP-126). HRE thanks Swedish Research Links grants (VR 2016-05908).

Acknowledgments: The authors wish to thank to Central Research and Animal Facility, Kulliyyah of Science, International Islamic University Malaysia for providing us the zebrafish facilities.

Conflicts of Interest: The authors declare no conflict of interest, and the sponsors had no role in the design, execution, interpretation, or writing of the study.

\section{References}

1. Hill, A.J.; Teraoka, H.; Heideman, W.; Peterson, R.E. Zebrafish as a model vertebrate for investigating chemical toxicity. Toxicol. Sci. 2005, 86, 6-19. [CrossRef]

2. Howe, K.; Clark, M.; Torroja, C.; Torrance, J.; Berthelot, C.; Muffato, M.; Collins, J.E.; Humphray, S.; McLaren, K.; Matthews, L.; et al. The zebrafish reference genome sequence and its relationship to the human genome. Nature 2013, 496, 498-503. [CrossRef]

3. Lieschke, G.J.; Currie, P.D. Animal models of human disease: Zebrafish swim into view. Nat. Rev. Genet. 2007, 8, 353-367. [CrossRef] [PubMed]

4. Biemar, F.; Argenton, F.; Schmidtke, R.; Epperlein, S.; Peers, B.; Driever, W. Pancreas development in zebrafish: Early dispersed appearance of endocrine hormone expressing cells and their convergence to form the definitive islet. Dev. Biol. 2001, 230, 189-203. [CrossRef] 
5. Wendik, B.; Maier, E.; Meyer, D. Zebrafish mnx genes in endocrine and exocrine pancreas formation. Dev. Biol. 2004, 268, 372-383. [CrossRef]

6. Tabassum, N.; Tai, H.; Jung, D.W.; Williams, D.R. Fishing for Nature's Hits: Establishment of the Zebrafish as a Model for Screening Antidiabetic Natural Products. Evidence-based Complement. Altern. Med. 2015, 2015. [CrossRef] [PubMed]

7. de Carvalho Junior, A.R.; Vieira, I.J.C.; de Carvalho, M.G.; Braz-Filho, R.; S Lima, M.A.; Ferreira, R.O.; José Maria, E.; de Oliveira, D.B. ${ }^{13}$ C-NMR Spectral Data of Alkaloids Isolated from Psychotria Species (Rubiaceae). Molecules 2017, 22, 103.

8. Currais, A.; Chiruta, C.; Goujon-Svrzic, M.; Costa, G.; Santos, T.; Batista, M.T.; Paiva, J.; do Céu Madureira, M.; Maher, P. Screening and identification of neuroprotective compounds relevant to Alzheimer's disease from medicinal plants of S. Tomé e Príncipe. J. Ethnopharmacol. 2014, 155, 830-840. [CrossRef] [PubMed]

9. Formagio, A.S.N.; Volobuff, C.R.F.; Santiago, M.; Cardoso, C.A.L.; Vieira, M.D.C.; Valdevina Pereira, Z. Evaluation of antioxidant activity, total flavonoids, tannins and phenolic compounds in psychotria leaf extracts. Antioxidants 2014, 3, 745-757. [CrossRef]

10. Snyder, R.W.; Berns, J.S. Reviews: Use of insulin and oral hypoglycemic medications in patients with diabetes mellitus and advanced kidney disease. Semin. Dial. 2004, 17, 365-370. [CrossRef] [PubMed]

11. Gkaliagkousi, E.; Shah, A.; Ferro, A. Pharmacological and non-pharmacological treatment of endothelial dysfunction: Relevance to diabetes. Br. J. Diabetes Vasc. Dis. 2007, 7, 5-10. [CrossRef]

12. Intine, R.V.; Olsen, A.S.; Sarras, M.P. A Zebrafish Model of Diabetes Mellitus and Metabolic Memory. J. Vis. Exp. 2013, 72, 50232. [CrossRef]

13. Mostafavinia, A.; Amini, A.; Ghorishi, S.K.; Pouriran, R.; Bayat, M. The effects of dosage and the routes of administrations of streptozotocin and alloxan on induction rate of type1 diabetes mellitus and mortality rate in rats. Lab. Anim. Res. 2016, 32, 160-165. [CrossRef]

14. Sharif, K.M.; Rahman, M.M.; Azmir, J.; Khatib, A.; Hadijah, S.; Mohamed, A.; Sahena, F.; Zaidul, I.S.M. Orthogonal partial least squares model for rapid prediction of antioxidant activity of Pereskia bleo by Fourier transform infrared spectroscopy. Anal. Lett. 2014, 47, 2061-2071. [CrossRef]

15. Elsner, M.; Guldbakke, B.; Tiedge, M.; Munday, R.; Lenzen, S. Relative importance of transport and alkylation for pancreatic beta-cell toxicity of streptozotocin. Diabetologia 2000, 43, 1528-1533. [CrossRef]

16. Parkman, H.P.; Fass, R.; Foxx-Orenstein, A.E. Treatment of patients with diabetic gastroparesis. Gastroenterol. Hepatol. 2010, 6, 1 .

17. Jörgens, K.; Hillebrands, J.L.; Hammes, H.P.; Kroll, J. Zebrafish: A model for understanding diabetic complications. Exp. Clin. Endocrinol. Diabetes 2012, 120, 186-187. [CrossRef]

18. Shin, E.; Hong, B.N.; Kang, T.H. An optimal establishment of an acute hyperglycemia zebrafish model. Afr. J. Pharm. Pharmacol. 2012, 6, 2922-2928. [CrossRef]

19. Moss, J.B.; Koustubhan, P.; Greenman, M.; Parsons, M.J.; Walter, I.; Moss, L.G. Regeneration of the pancreas in adult zebrafish. Diabetes 2009, 58, 1844-1851. [CrossRef]

20. Szkudelski, T. The mechanism of alloxan and streptozotocin action in B cells of the rat pancreas. Physiol. Res. 2001, 50, 537-546.

21. Gorus, F.K.; Malaisse, W.J.; Pipeleers, D.G. Selective uptake of alloxan by pancreatic B-cells. Biochem. J. 1982, 208, 513-515. [CrossRef] [PubMed]

22. Lenzen, S.; Mirzaie-petri, M. Inhibition of glucokinase and hexokinase from pancreatic b-cells and liver by alloxan, alloxantin, dialuric acid, and i-butylhydroperoxide. Biomed. Res. 1991, 12, 297-307. [CrossRef]

23. Danial, N.N.; Gramm, C.F.; Scorrano, L.; Zhang, C.-Y.; Krauss, S.; Ranger, A.M.; Robert Datta, S.; Greenberg, M.E.; Licklider, L.J.; Lowell, B.B.; et al. BAD and glucokinase reside in a mitochondrial complex that integrates glycolysis and apoptosis. Nature 2003, 424, 952-956. [CrossRef]

24. Bedoya, F.J.; Solano, F.; Lucas, M. N-monomethyl-arginine and nicotinamide prevent streptozotocin-induced double strand DNA break formation in pancreatic rat islets. Experientia 1996, 52, 344-347. [CrossRef] [PubMed]

25. González, E.; Roselló-Catafau, J.; Jawerbaum, A.; Sinner, D.; Pustovrh, C.; Vela, J.; White, V.; Xaus, C.; Peralta, C.; Gimeno, M. Pancreatic nitric oxide and oxygen free radicals in the early stages of streptozotocin-induced diabetes mellitus in the rat. Brazilian J. Med. Biol. Res. 2000, 33, 1335-1342. [CrossRef] 
26. Lu, J.; Liu, K.; Schulz, N.; Karampelias, C.; Charbord, J.; Hilding, A.; Rautio, L.; Bertolino, P.; Östenson, C.; Brismar, K. IGFBP1 increases $\beta$-cell regeneration by promoting $\alpha$-to $\beta$-cell transdifferentiation. EMBO J. 2016, 35, 2026-2044. [CrossRef]

27. Beer, R.L.; Parsons, M.J.; Rovira, M. Centroacinar cells: At the center of pancreas regeneration. Dev. Biol. 2016, 413, 8-15. [CrossRef]

28. Luzi, L.; Pozza, G. Glibenclamide: An old drug with a novel mechanism of action? Acta Diabetol. 1997, 34, $239-244$. [CrossRef]

29. Müller, G. The mode of action of the antidiabetic drug glimepiride-beyond insulin secretion. Curr. Med. Chem. Immunol. Endocr. Metab. Agents 2005, 5, 499-518. [CrossRef]

30. Sola, D.; Rossi, L.; Schianca, G.P.C.; Maffioli, P.; Bigliocca, M.; Mella, R.; Corlianò, F.; Fra, G.P.; Bartoli, E.; Derosa, G. Sulfonylureas and their use in clinical practice. Arch. Med. Sci. AMS 2015, 11, 840. [CrossRef]

31. Joya-Galeana, J.; Fernandez, M.; Cervera, A.; Reyna, S.; Ghosh, S.; Triplitt, C.; Musi, N.; DeFronzo, R.A.; Cersosimo, E. Effects of insulin and oral anti-diabetic agents on glucose metabolism, vascular dysfunction and skeletal muscle inflammation in type 2 diabetic subjects. Diabetes. Metab. Res. Rev. 2011, 27, 373-382. [CrossRef] [PubMed]

32. Capiotti, K.M.; Antonioli, R.; Kist, L.W.; Bogo, M.R.; Bonan, C.D.; Da Silva, R.S. Persistent impaired glucose metabolism in a zebrafish hyperglycemia model. Comp. Biochem. Physiol. B: Biochem. Mol. Biol. 2014, 171, 58-65. [CrossRef] [PubMed]

33. Li, W.L.; Zheng, H.C.; Bukuru, J.; De Kimpe, N. Natural medicines used in the traditional Chinese medical system for therapy of diabetes mellitus. J. Ethnopharmacol. 2004, 92, 1-21. [CrossRef] [PubMed]

34. Chen, J.; Mangelinckx, S.; Adams, A.; Wang, Z.T.; Li, W.L.; De, N.K. Natural flavonoids as potential herbal medication for the treatment of diabetes mellitus and its complications. Nat. Prod. Commun. 2015, 10, 187-200. [CrossRef]

35. Hui, H.; Tang, G.; Go, V.L.W. Hypoglycemic herbs and their action mechanisms. Chin. Med. 2009, 4, 11. [CrossRef]

36. Jemain, M.R.M.; Musa'adah, M.N.; Rohaya, A.; Rashid, L.A.; Hadiani, I.N. In vitro antihyperglycaemic effects of some Malaysian plants. J. Trop. For. Sci. 2011, 23, 467-472.

37. Tadera, K.; Minami, Y.; Takamatsu, K.; Matsuoka, T. Inhibition of $\alpha$-glucosidase and $\alpha$-amylase by flavonoids. J. Nutr. Sci. Vitaminol. 2006, 52, 149-153. [CrossRef] [PubMed]

38. Yanardağ, R.; Bolkent, Ş.; Tabakoğlu-Oğuz, A.; Özsoy-Saçan, Ö. Effects of Petroselinum crispum extract on pancreatic B cells and blood glucose of streptozotocin-induced diabetic rats. Biol. Pharm. Bull. 2003, 26, 1206-1210. [CrossRef]

39. Miyazawa, M.; Yagi, N.; Taguchi, K. Inhibitory compounds of $\alpha$-glucosidase activity from Arctium lappa L. J. Oleo Sci. 2005, 54, 589-594. [CrossRef]

40. Liu, L.; Deseo, M.A.; Morris, C.; Winter, K.M.; Leach, D.N. Investigation of $\alpha$-glucosidase inhibitory activity of wheat bran and germ. Food Chem. 2011, 126, 553-561. [CrossRef]

41. Ortiz-Andrade, R.R.; Garcia-Jimenez, S.; Castillo-Espana, P.; Ramirez-Avila, G.; Villalobos-Molina, R.; Estrada-Soto, S. $\alpha$-Glucosidase inhibitory activity of the methanolic extract from Tournefortia hartwegiana: An anti-hyperglycemic agent. J. Ethnopharmacol. 2007, 109, 48-53. [CrossRef] [PubMed]

42. Muraoka, O.; Ying, S.; Yoshikai, K.; Matsuura, Y.; Yamada, E.; Minematsu, T.; Tanabe, G.; Matsuda, H.; Yoshikawa, M. Synthesis of a nitrogen analogue of salacinol and its $\alpha$-glucosidase inhibitory activity. Chem. Pharm. Bull. 2001, 49, 1503-1505. [CrossRef] [PubMed]

43. Teng, H.; Chen, L. $\alpha$-Glucosidase and $\alpha$-amylase inhibitors from seed oil: A review of liposoluble substance to treat diabetes. Crit. Rev. Food Sci. Nutr. 2017, 57, 3438-3448. [CrossRef]

44. Kandra, L.; Gyémánt, G.; Zajácz, Á.; Batta, G. Inhibitory effects of tannin on human salivary $\alpha$-amylase. Biochem. Biophys. Res. Commun. 2004, 319, 1265-1271. [CrossRef] [PubMed]

45. Murugesu, S.; Ibrahim, Z.; Ahmed, Q.-U.; Nik Yusoff, N.-I.; Uzir, B.-F.; Perumal, V.; Abas, F.; Saari, K.; El-Seedi, H.; Khatib, A. Characterization of $\alpha$-Glucosidase Inhibitors from Clinacanthus nutans Lindau Leaves by Gas Chromatography-Mass Spectrometry-Based Metabolomics and Molecular Docking Simulation. Molecules 2018, 23, 2402. [CrossRef]

46. Bursell, S.-E.; King, G.L. Can protein kinase C inhibition and vitamin E prevent the development of diabetic vascular complications? Diabetes Res. Clin. Pract. 1999, 45, 169-182. [CrossRef]

47. Joshi, S.R.; Standl, E.; Tong, N.; Shah, P.; Kalra, S.; Rathod, R. Therapeutic potential of $\alpha$-glucosidase inhibitors in type 2 diabetes mellitus: An evidence-based review. Expert Opin. Pharmacother. 2015, 16, 1959-1981. [CrossRef] 
48. Chougale, A.D. Optimization of Alloxan Dose is Essential to Induce Stable Diabetes for Prolonged Period Ashok D. Chougale, Shrimant N. Panaskar, Pradeep M. Gurao and Akalpita U. Arvindekar Department of Biochemistry, Shivaji University, Kolhapur, 416 004, India. Asian J. Biochem. 2007, 2, 402-408.

49. Capiotti, K.M.; De Moraes, D.A.; Menezes, F.P.; Kist, L.W.; Bogo, M.R.; Da Silva, R.S. Hyperglycemia induces memory impairment linked to increased acetylcholinesterase activity in zebrafish (Danio rerio). Behav. Brain Res. 2014, 274, 319-325. [CrossRef]

50. Elo, B.; Villano, C.M.; Govorko, D.; White, L.A. Larval zebrafish as a model for glucose metabolism: Expression of phosphoenolpyruvate carboxykinase as a marker for exposure to anti-diabetic compounds. J. Mol. Endocrinol. 2007, 38, 433-440. [CrossRef]

51. Javadi, N.; Abas, F.; Hamid, A.A.; Simoh, S.; Shaari, K.; Ismail, I.S.; Mediani, A.; Khatib, A. GC-MS-Based Metabolite Profiling of Cosmos caudatus Leaves Possessing Alpha-Glucosidase Inhibitory Activity. J. Food Sci. 2014, 79, C1130-C1136. [CrossRef] [PubMed]

52. Khatib, A.; Yuliana, N.D.; Jinap, S.; Sarker, M.Z.I.; Jaswir, I.; Wilson, E.G.; Chung, S.-K.; Verpoorte, R. Identification of possible compounds possessing adenosine A1 receptor binding activity in the leaves of Orthosiphon stamineus using TLC and multivariate data analysis. J. Liq. Chromatogr. Relat. Technol. 2009, 32, 2906-2916. [CrossRef]

53. Bancroft, J.D.; Gamble, M. Theory and Practice of Histological Techniques, 6th ed.; Elsevier Health Sciences: Philadelphia, PA, USA, 2008; pp. 53-121.

54. Tsao-Wu, G.S.; Weber, C.H.; Budgeon, L.R.; Cheng, K.C. Agarose-embedded tissue arrays for histologic and genetic analysis. Biotechniques 1998, 25, 614-618. [CrossRef]

55. Copper, J.E.; Budgeon, L.R.; Foutz, C.A.; van Rossum, D.B.; Vanselow, D.J.; Hubley, M.J.; Clark, D.P.; Mandrell, D.T.; Cheng, K.C. Comparative analysis of fixation and embedding techniques for optimized histological preparation of zebrafish. Comp. Biochem. Physiol. C Toxicol. Pharmacol. 2018, 208, 38-46. [CrossRef] [PubMed]

56. Matthews, M.; Varga, Z.M. Anesthesia and euthanasia in zebrafish. ILAR J. 2012, 53, 192-204. [CrossRef] [PubMed]

Sample Availability: Sample of the P. malayana leaf is not available from the authors.

(C) 2019 by the authors. Licensee MDPI, Basel, Switzerland. This article is an open access article distributed under the terms and conditions of the Creative Commons Attribution (CC BY) license (http://creativecommons.org/licenses/by/4.0/). 